\title{
Gender Specialization in Households: An Empirical Analysis ${ }^{*}$
}

\author{
Francesc Ortega \\ Universitat Pompeu Fabra
}

\author{
Ryuichi Tanaka \\ Tokyo Institute of Technology
}

January 2007

\begin{abstract}
This paper studies the effect of parental education on the educational attainment of children in the US for cohorts born after 1910. Importantly, we allow for cohort-specific differences by gender. Our estimates show that paternal education has been more important for the attainment of male children (paternal specialization on sons). However, maternal specialization (on daughters) seems to have appeared only for cohorts born after 1955 . We interpret these results as evidence that fathers are more important role models for sons while mothers are a more important reference for daughters. We argue that our results are robust to the presence of hereditary unobserved ability and conjecture that both types of gender specialization may have been present in earlier cohorts too.
\end{abstract}

JEL classification: I20, J16, D13

Keywords: Ability, Gender, Human capital, Educational Economics

\footnotetext{
* The authors thank the Spanish Ministry for Science and Education for generous financial support (SEJ2005-08110).
} 
Whose education matters more for the educational attainment of children: the father's or the mother's? Does the father's education affect the educational attainment of sons and daughters equally? And the mother's? This paper revisits these questions and examines how the answers have changed in recent times. We present a cohort analysis of the relation between the educational attainment of parents and children, with a special emphasis on gender differences.

The novelty of our study is the focus on many cohorts, spanning most of the twentieth century. Over this period American families have undergone a deep transformation, particularly due to the spectacular increase in female labor force participation. It is quite likely that, as a result, the effect of parental education as a determinant of the educational attainment of children may have changed substantially. Moreover, one would expect also changes in the relative influence of maternal and paternal education on the attainment of children. For instance, as wives became wage earners, it is likely that their influence in decision-making within households increased, which may have affected investment patterns on sons and daughters, as well as children's attitudes toward education and work. $^{1}$

Our focus on a long time span conditions the data available to us. In particular, we do not have a direct way to control for hereditary ability. We are aware of the potential sources of bias and derive estimators that are robust to this fact. More specifically, our analysis is based on the differential effect that parents education has on the attainment of male and female children. Along these lines, we say that there is maternal specialization (on daughters) when mothers' education has a larger effect on the attainment of daughters than on that of sons. Analogously, we refer to paternal specialization (on sons) when fathers' education has a larger effect on the attainment of sons than on that of daughters. We provide conditions for consistent estimation of gender specialization in the presence of unobserved ability.

We find paternal specialization (on sons) for all cohorts included in our analysis. However, we find maternal specialization (on daughters) only for cohorts born after 1955. We argue that maternal

\footnotetext{
${ }^{1}$ Pasqua (2005) discusses several theoretical explanations for gender bias in educational investments.
} 
specialization may have been present for earlier cohorts as well. However, our estimates for earlier cohorts may have been biased due to gender-asymmetric effects of family income on the educational attainment of children (favoring sons over daughters).

A large literature in social sciences has looked at parental inputs in the development of children and, in particular, at which parent's education plays a bigger role in the process. In an extensive review of the literature Haveman and Wolfe (1995) find that a majority of papers suggest a more important role of maternal education but also note the lack of consensus. The debate on the relative contribution of paternal and maternal input has been reignited by a recent and provocative contribution. Behrman and Rosenzweig (2002) find that maternal education has no (direct) effect on the education of children and that the father's education matters more than the mother's. Black et al (2005) also attempt to estimate the causal effects of parental education on the attainment of children using Norwegian data. They do allow for gender differences of parents and children. Their main result is that paternal education has a negligible direct effect on the educational outcomes of both sons and daughters. In contrast, maternal education has a positive, small and significant effect on the attainment of sons, but not of daughters. ${ }^{2}$ That is, they find evidence that (Norwegian) mothers "specialized" in sons in the time period they consider. ${ }^{3}$

Cross-country differences in gender specialization have also been documented. ${ }^{4}$ Using Turkish data, Tansel (2002) finds maternal specialization (on daughters) but finds that fathers' education matters more for daughters than for sons. Using Australian data, Le, Miller, Heath, and Martin (2005) find evidence in favor of both maternal specialization (on daughters) and paternal specialization (on sons). Their results also suggest that paternal education is a more important determinant of the educational attainment of children than maternal education, both for male and female children.

\footnotetext{
2 They obtain this result when including only one parent's education "at a time" in their regressions. When they include both parents' education simultaneously (as we do), they still find no significant effects of the father's education (on both sons and daughters). However, this time they find a positive significant effect of maternal education on daughters' attainment (but not on sons), that is, maternal specialization in our jargon.

${ }^{3}$ It would be interesting to know if their results change when considering maternal work status during childhood of the respondent.

${ }^{4}$ Lundberg and Rose (2002) introduce an alternative concept of household specialization. They document that an increase in family size leads households to specialize in their labor supply.
} 
Using anthropometric data for a variety of countries, Thomas (1994) finds that maternal inputs (education and non-labor income) have a larger effect on daughters than on sons while paternal inputs are more important for sons. ${ }^{5}$ That is, his results suggest the existence of both types of gender specialization. Furthermore, he argues that the actual investment levels on sons and daughters reflect the relative bargaining power of each parent.

However, to the best of our knowledge, no studies so far have examined how the relation between parental input and children's educational attainment may have changed over time. In our analysis, we use micro data from the General Social Survey (GSS). We classify all respondents who reported the educational attainment of both parents by year of birth and we estimate the degree of gender specialization, which we allow to vary across cohorts and genders.

The GSS provides information on the educational levels of parents and children for many cohorts but lacks data that can be used to control for unobserved ability. To deal with this problem, we develop estimators of parental gender specialization that are consistent even in the presence of hereditary unobserved ability. Several approaches have been proposed to control for unobserved ability. These papers can be classified in four categories. One approach uses test scores of young children as a proxy for ability (Cameron and Heckman 2001, Bernal 2006). A second approach uses instrumental variable estimation. Currie and Moretti (2003) use data on college availability as an instrument for maternal education. Instead, Chevalier (2004) and Black et al (2005) instrument parental education using changes in compulsory schooling laws, in a similar fashion to Acemoglu and Angrist (2000), who use the same approach to estimate the social returns to education. A third approach is the within-twin estimator proposed by Behrman and Rosenzweig (2002), who use a sample of identical twins. Finally, Plug (2002) and Plug and Vijvergerg (2005) use adoptees data to control for unobserved ability. These approaches require very detailed data, not available for long periods of time.

Our paper is closely related to some recent contributions to the vast literature on the effect of family

\footnotetext{
${ }^{5}$ More specifically, Thomas focuses on the effect of parental education on children's height, a measure that has been found to correlate strongly with a child's long-run health and to wages as an adult in developing countries. The results do not seem to depend on the exact anthropometric indicator used. Thomas (1990) examines the effects on child's weight for height and finds the similar pattern of gender specialization.
} 
background on children's outcomes. Raaum et al (2006) perform a cohort analysis to compare the relative contribution of family background and neighborhood characteristics to children's outcomes (education and income) using Norwegian data. Their dataset is very rich and spans cohorts born in the period 1946-65. They find that family background has a larger and increasing explanatory power. In their analysis, they also need to deal with the potential bias introduced by time trends in unobserved family background.

Finally, our paper is also related to the strand of literature studying resource allocation within households with children. Millimet (2000) builds a model where families jointly determine their fertility and labor supply decisions. Based on the model, he proposes an estimator of the impact of fertility on the labor supply and wages of husbands and wives. Using PSID data he finds that children increase specialization in households between work at home and outside, raising wage differentials between husbands and wives. Within this literature there is a recent surge of work on the effects of early maternal employment on investments in young children, as captured by measures of cognitive ability. Bernal (2006) estimates a structural model using data from the NLSY and finds negative effects of maternal employment on children. More closely related to our approach, Gregg et al (2005) carry out an analysis based on a single cohort of children born in 1991-1992 but, as in our case, do not have all the necessary data to directly control for unobserved ability. Their strategy is to examine how their estimates vary when they include additional sets of variables aimed at proxying for unobservables. They find that the effect depends on the type of non-maternal childcare. The authors also point out that this effect is only part of the total effect of maternal employment on children's outcomes measured later in life. In particular, maternal employment may have behavioral and socio-emotional effects too. ${ }^{6}$ Our work can thus be seen as a complement to their analysis since our focus on gender specialization is closely related to parents becoming role models for their same-gender children.

The structure of the paper is as follows. Section 2 contains our analysis of parental education for the cohorts born after 1935. The educational attainment of these cohorts does not seem to be influenced by the temporary shock to the American labor market caused by the onset of World War II. In this

${ }^{6}$ Leibowitz (2003) emphasizes the importance of in-home training for children's cognitive development. Her findings suggest that maternal labor force participation may have negative effects on very young children (below the age of one). 
section we ignore the potential effect of unobserved ability on our estimates. Section 3 explicitly considers the effects of unobservables and presents our estimators of gender specialization. Section 4 exploits data on the work status of mothers to sharpen our results. Section 5 extends the analysis back to cohorts born since 1910. Section 6 concludes. The appendix contains sensitivity analysis and background data about the evolution of female labor force participation in the US.

\section{$2 \quad$ Who matters more? A cohort analysis}

We are interested in the effects of parental education for the educational attainment of the US cohorts born after 1935. In particular, we would like to know whose parent's education is more decisive in the education of children: the father's or the mother's, and whether there are differences in parental roles by gender of the child.

To carry out the exercise, we construct a dataset of microdata using the GSS, as described below. We classify individuals in 5-year (birth) cohorts and fit the following regression cohort by cohort. The two regressions below are estimated using, respectively, the subsample of males (sons) and the subsample of females (daughters) belonging to cohort t. Thus, for individuals of gender $g=s, d$ (for sons and daughters) born in year $t$, we estimate

$$
\begin{aligned}
& e d u c_{i}=\beta_{0}^{s, t}+\beta_{p}^{s, t} \text { paeduc }_{i}+\beta_{m}{ }^{s, t} \text { maeduc }_{i}+\beta^{s, t} Z_{i}+\varepsilon_{i}, \quad \text { for } \quad i=1, \ldots, n_{s, t} \\
& e d u c_{i}=\beta_{0}^{d, t}+\beta_{p}^{d, t} \text { paeduc }_{i}+\beta_{m}{ }^{d, t} \text { maeduc }_{i}+\beta^{d, t} Z_{i}+\varepsilon_{i}, \quad \text { for } \quad i=1, \ldots, n_{d, t}
\end{aligned}
$$

where $e d u c_{i}$ is the years of education of individual $i$. Respectively, paeduc $c_{i}$ and maeduc $c_{i}$ stand for the years of education of individual $i$ 's father and mother, and $Z_{i}$ is a vector of family characteristics that includes variables such as the number of siblings. This is essentially the regression model in Card and Lemieux (2000), however we allow for greater heterogeneity in the coefficients of the regression. In particular, we allow the coefficients of parental education to vary across cohorts and genders. ${ }^{7}$ Note that all coefficients are allowed to vary across cohorts and genders. The birth cohorts considered are $t=1935-39, \ldots, 1965-69$. Prior to showing the estimation results, we

\footnotetext{
${ }^{7}$ Similar regressions have been estimated in Kremer (1997), Fernández and Rogerson (2001) using the PSID, and Fernández, Fogli and Olivetti (2002) using the GSS.
} 
provide some summary statistics of the sample.

\subsection{Data}

Our data source is the General Social Survey (GSS), 1972-2000. We pool together all individuals surveyed in the different waves that reported their educational attainment (years of completed education) and the educational attainment of both of their parents. In addition, we restrict our sample to individuals who were at least 25 years old at the time of the interview. The reason is that we want to allow respondents to have had enough time to complete their 'desired' level of education. ${ }^{8}$ Then we classify individuals by their year of birth, independently of when they were interviewed. In order to increase the density of observations in each cell, we construct 5-year cohorts.

Tables 1.1 and 1.2 report descriptive statistics for our sample, by gender and cohort. We report sample means and standard deviations for birth cohorts 1935-1969. Observe first that the average age at the time of the interview is decreasing by year of birth cohort. For the individuals in our sample, the average years of education of their fathers and mothers (paeduc and maeduc) are strictly increasing across cohorts. The same is not true, however, about the average years of education of the respondents. For males, average educational attainment increased monotonically from around 11 years for the 1910-14 cohort up to 14.20 years for the 1945-49 cohort. However, birth cohorts 1950-54 and 1955-59 experienced a drop in their average education, relative to the preceding cohorts. ${ }^{9}$ In fact, the average educational attainment of males born in 1965-69 was 14.10 years, below the attainment of the 1945-49 cohort. For females, educational attainment did not drop but it slowed down, close to stagnation, for the cohorts 1950-54 to 1960-64.

We also report the correlation coefficient between the years of education of the respondent and those of each of the parents. Observe that the four correlations are quite high, on average above 0.4. The correlation with maternal education ranges from 0.37 to 0.50 , while the correlation with paternal education ranges from 0.30 to 0.50 . The correlation between the education of husbands and

${ }^{8}$ One may worry that a fraction of the population may not have completed their desired education by age 25 . We tackle this question a bit later.

9 This fact is well known in the literature. See, for instance, Card and Lemieux (2000) for an account using different data sources. 
wives is very high and quite constant across cohorts, ranging from 0.50 to $0.70{ }^{10}$

An important observation that stands out from these statistics is how similar they are for the subsamples of men and women. This is natural given that the gender of the children can be thought of as being exogenous to a given family. This observation will play an important role later on.

Tables 6.1 and 6.2 report the same statistics as tables 1.1 and 1.2, but for the sample of individuals aged 30 or above at the time of the interview. It is interesting to point out that the average educational attainment of the cohorts in this sample is remarkably similar to that of the younger sample. In particular, let us note that the average educational attainment of the latest cohorts is practically the same for both subsamples. This observation suggests that educational attainment at age 25 (at interview) is a reasonable measure of 'final' educational attainment. In any case, we will check the sensitivity of our results by using this alternative sample.

\subsection{Regression estimates}

We estimate regression (1) and (2) using the previously described sample. The estimates are summarized in tables 2.1 and 2.2 and figures 1.1-1.3.

Let us start with paternal education. First of all, observe that the father's education has a larger effect on sons than on daughters. In figure 1.1, the coefficient on paternal education is larger for sons than for daughters in all cohorts (except the first one). We shall refer to this feature as paternal specialization (on sons) and use the difference between the coefficients for sons and daughters to measure it. The figure shows a small but persistent paternal specialization across all generations (not significant at the usual significance levels). We also note an upward trend in the influence of the father's education both on sons and daughters. The estimated coefficients, for both genders, start at 0.12 for the 1935-39 cohort and end up at 0.20 , for daughters, and at 0.23 for sons.

\footnotetext{
${ }^{10}$ For more on marital sorting in the U.S., see Mare (1991).
} 
Let us turn now to maternal education. Figure 1.2 shows a striking difference in the evolution of the maternal role, depending on the child's gender. While the maternal role has remained quite constant for daughters (at around 0.2), it displays a clear downward trend for sons, accelerating for the 1950-54 and following cohorts. The coefficient of maternal education for sons has dropped from 0.20 to 0.05 in the time period considered. Does maternal education have a larger effect on the education of sons or on the education of daughters? For cohorts born before 1950, the mother's education has an indistinguishable effect on sons and daughters. However, for the children born in the 1950s or afterward, the mother's education has played a bigger role in the educational attainment of daughters than on the attainment of sons. Define now maternal specialization (on daughters) as the difference between the coefficients on daughters and sons. Then figure 1.2 features increasing maternal specialization for all cohorts born after 1955. Note that for the cohorts born in the 1960s, there is a significant degree of maternal specialization (at the usual significance levels). Taken together, figures 1.1 and 1.2, point to a situation of (same) gender specialization within American households for the cohorts born after 1955.

Figure 1.3 contains the estimated intercepts, which take values around nine (years of education), which can be interpreted as the years of compulsory education. ${ }^{11}$ It is worth pointing out that the estimated intercepts are higher for men than for women, which suggests that the intercept also captures differences in the perceived returns to schooling for men and women.

The appendix contains sensitivity analysis of these results. We re-estimate again the same regressions but on a sample containing only those individuals who were at least thirty years old at the time of the interview. In general, the two earlier findings are confirmed.

\section{$3 \quad$ Estimation of gender specialization patterns}

\footnotetext{
11 Acemoglu and Angrist (2000) use changes in compulsory laws to estimate the private and social returns to schooling in the US.
} 
This section discusses the empirical evidence on the consequences of ignoring unobserved ability. We also provide a simple model, where unobserved ability is explicitly considered, and derive estimators of the effects of parental education on the attainment of children that are robust to unobserved ability.

\subsection{Unobserved ability}

The literature on family background and educational attainment has provided abundant evidence supporting that the estimators for parental education in the above regressions are likely to be biased. Behrman and Rosenzweig (2002) point out that to the extent that ability is genetically transmitted and not accounted for in the regression, two types of bias affect least-squares estimates of the effects of parental education on educational attainment. Having a highly educated mother is associated to being high ability for two reasons. First, a high-education mother is likely to signal a high-ability mother, and hence, a high-ability child through genetic transmission (ability bias). On top of that, a high-education mother is likely to have married a high ability man. Again, genetic transmission of ability makes it more likely that the child is high ability (marital sorting bias).

Using data on identical twins, Behrman and Rosenzweig (2002) propose a within-twin estimator that allows for an unbiased estimation of the effect of maternal education in the presence of unobserved ability. ${ }^{12}$ They conclude that maternal education has virtually no effect on children's educational attainment. ${ }^{13}$ Their interpretation is that despite the benefits from being born to a more educated mother, given that education and labor force participation are positively correlated, it is likely that a more educated mother will spend more time working (outside the home), and the two effects may offset each other. Their results also suggest that OLS estimates are substantially upwardly biased.

\footnotetext{
12 Their dataset contains 424 female (identical) twins and 244 male (identical) twins born in Minnesota between 1936 and 1955 .

${ }^{13}$ Unfortunately they do not report the results separately by gender of the children. Antonovics and Goldberger (2003) point out some problems in data construction in Behrman and Rosenzweig (2002) and redo the analysis. The conclusion that paternal education plays a larger role than maternal education remains unchanged.
} 
We lack any information that can be used to control for unobserved ability in our dataset so our earlier OLS estimates are possibly biased for the reasons outlined above. However, in this section we provide an estimator of the gender differences in the effects of the education of each parent that is consistent even in the presence of unobserved ability.

\subsection{A simple model}

An important lesson from the literature on educational attainment and family background is that unobserved ability cannot be ignored when estimating the effects of parental education. To be explicit about the role of unobserved ability, we construct a simple model and use it to derive consistent estimators of the gender differences of the effects of parental education. The model provides a structural interpretation for the regressions reported in the previous section.

We have in mind a setup where each individual, say in her teens, chooses her total years of education. Her choice depends on her ability and her family's income, as well as other family characteristics. In addition, her choice and the choices of all individuals in the same cohort are also affected by features of the macroeconomic environment, such as the returns to schooling and the returns to alternative uses of time.

Parental education has two main functions. First, it is a determinant of family income, which is an important input in ability formation. Children born in families with high income receive better early education and better health care. Parental education also determines the child's preferences over education, for instance by affecting their personal goals and aspirations. In this process, it is possible that gender effects are present. That is to say, it may be that a female child who is raised in a household where only the mother is college educated is more likely to want to get a college degree herself than if she grew up in a household where only the father was college educated. In other words, the exact distribution of education over the parents may matter in shaping children's preferences over education, and hence, the educational choices of male and female children.

Let us now introduce some notation. Let the family background of a generic individual $i$ be summarized by the years of education and ability levels of each parent, as well as household income Ii. Let the father's years of education and ability level be denoted by $\left(y_{p, i}, h_{p, i}\right)$. Analogously, the 
mother characteristics are given by $\left(y_{m, i}, h_{m, i}\right){ }^{14}$ In short, an individual's family background is given by $\left(y_{p, i}, h_{p, i}, y_{m, i}, h_{m, i}, I_{i}\right)$.

We assume that children inherit some ability from their parents according to

$h_{i}=b_{p} h_{p, i}+b_{m} h_{m, i}$.

We think of this transmission as being mainly biological. Thus, we assume it is invariant across genders and birth cohorts.

Individual education outcomes are supposed to depend on parental education $\left(y_{p, i}, y_{m, i}\right)$, family income $\left(I_{i}\right)$ and own ability $\left(h_{i}\right)$. As argued, parental education can be interpreted as shaping children's preferences over education. An alternative interpretation is that parents can increase the ability of their children by spending time with them and the productivity of this investment may increase in their levels of education. Bernal (2006) follows this route. ${ }^{15}$

Family income also affects educational attainment. A new wave of research in labor economics suggests it is during childhood that family income plays the key role in (total) educational attainment (Keane and Wolpin, 2001, and Cameron and Heckman, 2001). We allow for family income to have asymmetric effects on the attainment of children.

Hence, the years of education of an individual $i$, born in cohort $t$, of gender $g=s, d$ are given by

$y_{i}=\beta_{0}^{g, t}+\beta_{p}^{g, t} y_{p, i}+\beta_{p}^{g, t} y_{m, i}+\beta_{I}^{g, t} I_{i}+h_{i}+u_{i}$

where $u_{i}$ is an idiosyncratic shock. Individual heterogeneity in educational attainment thus results from differences in family background, differences in unobserved ability and different values of idiosyncratic shock $u_{i}$.

\footnotetext{
${ }^{14}$ We shall use subindex $p$ to denote paternal variables. Similarly, subindex $m$ will denote maternal variables.

${ }^{15}$ Her paper also contains an excellent review of the literature. To read more on the determinants of ability see also Cameron and Heckman (2001).
} 


\subsection{Estimation}

Equation (3) provides an interpretation to the coefficients of regressions (1) and (2). In particular, observe that in our model the coefficients of parental education may vary across cohorts for a number of reasons. For instance, it may be because of differences across cohorts in the mapping from parental education to the child's preferences over education. This provides interpretations for why our earlier (possibly biased) OLS estimates of regressions (1) and (2) changed across cohorts.

In the estimation of the equation (3), individual ability and family income are unobserved. ${ }^{16}$ Hence, these unobserved terms are lodged in the error term when we estimate this equation.

Let us now derive estimators of the effect of parental education that are consistent in the presence of unobserved ability. It is plausible that some decades ago families invested more heavily in the education of their male children, given that women tended to stay at home. This situation has changed radically in recent times.

Assuming that the family backgrounds of boys and girls are drawn from the same population distribution, the probability limit of the OLS estimator of equation (3) is given by

$\hat{\beta}^{g, t}=\beta^{g, t}+\left(E\left(X^{\prime}{ }_{t} X_{t}\right)\right)^{-1}\left(E\left(X^{\prime}{ }_{t} I_{t}\right) \beta_{I}{ }^{g, t}+E\left(X^{\prime}{ }_{t} h_{p}\right) b_{p}+E\left(X^{\prime}{ }_{t} h_{m}\right) b_{m}\right)$,

where $\beta^{g, t}=\left(\beta_{0}^{g, t}, \beta_{p}^{g, t}, \beta_{m}{ }^{g, t}\right)$, and $X_{t}=\left(1, y_{p, t}, y_{m, t}\right)$ is a random sample of parental education from the population distribution of cohort $t$.

As already argued, identification of $\beta^{\text {s,t }}$, the effect of parental education on the educational attainment of children is not feasible with the available data. Hence, we shall remain silent about the levels or time trends in figures 1.1 and 1.2. However, the previous result states that we can identify gender-differential effects of each parent's education under the assumptions discussed above.

\footnotetext{
${ }^{16}$ We have some proxies for family income, for instance family size and location, but these are only crude measures of family income in the relevant time period.
} 
However, we note that the (probability limit of the) difference between the effect of parental education for sons and daughters is given by

$\hat{\beta}^{s, t}-\hat{\beta}^{d, t}=\beta^{s, t}-\beta^{d, t}+\left(\beta_{I}^{s, t}-\beta_{I}^{d, t}\right)\left(E\left(X^{\prime}{ }_{t} X_{t}\right)\right)^{-1} E\left(X^{\prime}{ }_{t} I_{t}\right)$.

The first term is the difference between the direct effect of parental education on the educational attainment of sons and daughters, and the second term is the probably asymmetric effect of household income for sons and daughters.

We define maternal specialization (on daughters) as the difference between the coefficient of maternal education on daughters relative to sons, that is,

$M S_{t}=\beta_{m}^{d, t}-\beta_{m}^{s, t}$.

Analogously, we define paternal specialization (on sons) as

$P S_{t}=\beta_{p}^{s, t}-\beta_{p}^{d, t}$

When both $M S$ and $P S$ are positive we shall say that households display gender specialization. In this case, maternal education influences the attainment of daughters more than the attainment of sons and, at the same time, paternal education has a greater influence on the attainment of sons than on the attainment of daughters.

Under the assumption that family income has symmetric effects on the educational attainment of sons and daughters, our estimators identify gender specialization of fathers and mothers. However, if educational investments are biased toward boys or girls, then the difference estimator delivers mixed information on gender specialization.

Currently the enrolment of girls in US colleges is higher than that of male students, which suggests 
that there is no gender asymmetry in investment patterns, that is, $\beta_{I}^{s, t}=\beta_{I}^{d, t}$. However, this has not always been the case. It is quite likely that in the past families discriminated against daughters. In that case, $\beta_{I}^{s, t}>\beta_{I}^{d, t}$, which would bias our estimators of gender specialization. We shall later come back to this important point.

Let us now give another look at our estimates and estimate paternal and maternal specialization for each cohort. Figure 1.4 plots the evolution of gender specialization across the different cohorts. Two features stand out: The sharp increase in maternal specialization for the cohorts born since 1955 and the relatively constant degree of paternal specialization across all cohorts. The analysis in this section has shown that these two results are not likely to be driven by the inability to control for unobserved ability, at least for the most recent cohorts when unobserved income is unlikely to have biased our estimates. The next section provides our interpretation of the changes over time in gender specialization.

\section{$4 \quad$ Asymmetric effects of unobserved income}

As argued in the previous section, our estimators of gender specialization rely on two assumptions. The first one is that the genetic transmission of ability from parents to children is symmetric for sons and daughters. Since this process is largely determined by biology, the assumption seems highly plausible. The second assumption that we have maintained in the previous section is that unobserved increases in income have the same effect on the educational attainment of sons and daughters. This second assumption is more controversial. In fact it is quite plausible that, in the cohorts born at the beginning of the twentieth century, male children were favored by their parents in educational investments. It is also quite likely that this gender-asymmetric effect of income has been greatly reduced over the course of the century. Informal evidence suggests that it has virtually disappeared for the most recent cohorts (in the US). This hunch is supported by the fact that, in the last few years, the majority of new students enrolled in US colleges have been female.

Our interpretation of the previous results is the following. We believe that both parental and maternal specialization may have been present throughout the whole period of our analysis. Extensive evidence in psychology suggests that fathers are role models for sons while mothers are 
role models for daughters.

The reason why we did not find maternal specification for the earlier cohorts may be that those cohorts were characterized by gender-asymmetric investment patterns in the education of children. Given that female labor force participation was quite low it was more profitable to invest more heavily in the education of sons. As argued earlier, this would have biased downward our estimator of maternal specialization. As social attitudes changed, the gender asymmetry would have vanished until having virtually disappeared for the cohorts born around 1970.

The remainder of this section provides two additional pieces of evidence in support of this interpretation. The first one is based on differences in decision-making in households where the mother is employed outside the home. The second one analyzes a natural experiment. During World War II there was a temporary surge in the labor force participation of American mothers. According to our conjecture, this would have lead to a temporary surge in maternal specialization for the cohorts affected.

\subsection{Maternal employment and intra-household bargaining}

We think it is possible that families with a working mother had a much lower gender bias in the educational investments on their children. The reason being that wage-earning mothers would have had greater bargaining power in their households that would have translated in a more equal treatment of sons and daughters regarding the household educational investments. In contrast in more traditional families, where the mother stayed at home, the decision maker would have been the father, which might have introduced a bias against educational investment in daughters, according to our hypothesis. Consequently, we expect to find sharper estimates of gender specialization in the sub-sample of families with working mothers.

Specifically, we use a question that the GSS included for a limited number of waves: "Did your mother work at least one year after you were born and before you started first grade?"17 This question seems particularly relevant given that recent studies highlight the importance of the

17 This is variable MAWKBORN in the GSS codebook. This variable has been used also by Fernandez, Fogli and Olivetti (2002). All respondents were born after World War II. 
mother-child interactions at very early ages. We are also aware of the potential selection bias into maternal employment. In that respect we note that we allow for gender specialization patterns to differ across the two types of families.

Suppose there are two types of households, indexed by $w=0$, 1 . In households with $w=1$, the mother is employed. In households with $w=0$, the mother is not employed. Ideally, we would like to carry out the estimation allowing for heterogeneous coefficients by mother's work status and by birth cohort. Unfortunately, we do not have enough observations to do that and we need to impose restrictions on the coefficients. We introduce cohort dummies but assume that parental education coefficients do not differ by birth cohort. We only use individuals born after 1950 in the estimation. More specifically, the model we estimate is

$y_{i}=\beta_{0}{ }^{g, t}+\beta_{p}{ }^{g, w} y_{p, i}+\beta_{p}{ }^{g, w} y_{m, i}+\beta_{Z} I_{i}+\varepsilon_{i}$

Let us adapt now the previous estimators of paternal and maternal specialization to incorporate differences in maternal work status. Respectively,

$$
\begin{aligned}
& \overline{M S}_{w}=\hat{\beta}_{m}^{d, w}-\hat{\beta}_{m}^{s, w} \\
& \overline{P S}_{w}=\hat{\beta}_{p}^{s, w}-\hat{\beta}_{p}^{d, w}
\end{aligned}
$$

where $w=0$ indicates that the mother did not work (outside the home) and the opposite for $w=1$. It is easy to see that these estimators are consistent under the assumption of a common distribution for the four subsamples $(g, w) \in\{s, d\} \times\{0,1\}$.

It is important to note that we are not assuming that, for a given gender, individuals with a working mother and with a non-working mother were sampled from the same distribution. ${ }^{18}$

Let us proceed now to the estimation of model (4). In this case estimating the model jointly for both types of households is more convenient. To do so, it will be useful to define a female dummy variable, $\mathrm{Fem}_{i}$, which takes value 1 when individual $i$ is a female (and zero otherwise) and dummy

18 Bernal (2006) provides convincing evidence against this assumption. 
variable $w_{i}$, which takes value 1 when the mother was employed. We can now rewrite (4) as

$$
\begin{aligned}
& y_{i}=\left(c_{0, t}+d_{0, t} \text { Fem }_{i}\right) \\
& +\left(c_{p}+d_{p} \text { Fem }_{i}+e_{p} w_{i}+f_{p} \text { Fem }_{i} w_{i}\right) y_{p, i} \\
& +\left(c_{m}+d_{m} \text { Fem }_{i}+e_{m} w_{i}+f_{m} \text { Fem }_{i} w_{i}\right) y_{m, i}+\beta Z_{i}+\varepsilon_{i} .
\end{aligned}
$$

It is easy to see that the parameters of interest for the estimation of parental gender specialization are

$$
\begin{aligned}
& P S_{w=0}=-d_{p}, \quad P S_{w=1}=-d_{p}-f_{p} \\
& M S_{w=0}=d_{m}, \quad M S_{w=1}=d_{m}+f_{m} .
\end{aligned}
$$

Table 4.1 presents our estimates of the regression parameters and table 4.2 reports the estimated values for parental gender specialization for each type of household. We find that

$$
\begin{array}{ll}
\overline{M S}_{w=0}=0.065, & \overline{M S}_{w=1}=0.117 \\
\overline{P S}_{w=0}=0.057, & \overline{P S}_{w=1}=0.152
\end{array}
$$

that is, when the mother works both paternal specialization and maternal specialization increase substantially (duplicate or triplicate). In table 4.2 we also report the results of a number of significance tests. Using F-tests, we test (separately) the following null hypotheses: $M S_{w=0}=0$, $M S_{w=1}=0, P S_{w=0}=0$ and $P S_{w=1}=0$.

We find significant paternal specialization (on sons) and maternal specialization (on daughters) for families with working mothers (at the usual 5\% significance level). However, we do not find significant gender specialization in more traditional families where mothers are not employed. ${ }^{19}$ This provides supportive evidence for our conjecture that gender specialization may have been present for cohorts born before 1955 as well.

\footnotetext{
${ }^{19}$ As sensitivity analysis, we have also estimated our model on more homogeneous subsamples, born in the same 5-year cohort. We also find evidence of gender specialization in families with a working mother, although the evidence is weaker due to the smaller number of observations.
} 


\subsection{Maternal employment during World War II}

This section extends the analysis back to all cohorts born since 1910 and discusses instances of gender specialization present in the literature. The interest of this exercise is that it incorporates a temporary (and exogenous) surge in maternal employment around World War II. We expect maternal employment to increase temporarily for the children that were growing up during the event.

We proceed as before and summarize our results in tables 5.1 and 5.2, which extend tables 3.1 and 3.2. Figure 2.4 plots the evolution of parental gender specialization for all cohorts born between 1910 and 1969.

Over the longer horizon, we again find a relatively constant (small) degree of paternal specialization. Regarding maternal education, we note the existence of two episodes of maternal specialization: for cohorts born after 1955 and for cohorts born in 1930-34. ${ }^{20}$

Notice that the children born in cohort 1930-34 were roughly age 10 during World War II. Acemoglu, Autor and Lyle (2004) report that as a result of World War II American women entered the labor market in large numbers but this effect was just a temporary phenomenon. Five years after the War, the fraction of women in the labor market was back at its pre-war levels. The temporary increase in maternal specialization in figure 2.4 is consistent with our prediction. The increase in the number of families with working mothers (whose intrahousehold bargaining power had increased) would have temporarily mitigated the gender bias in educational investments and, as a result, would have allowed us to identify more sharply the true degrees of gender specialization.

\section{Concluding Remarks}

A recent trend in Economics takes households as the unit of analysis in the hope of enhancing our understanding of several important economic issues. Progress in this area requires enhancing our

\footnotetext{
${ }^{20}$ For the cohorts born in 1910-19, maternal specialization is also noticeable. We ignore this fact because of the small number of individual observations for this cohort.
} 
knowledge of human capital production in households. In particular, what are the effects of increasing parental education on the educational attainment of children? Do these effects depend on whose parent is obtaining more education?

This paper has attempted to address the latter question by analyzing the experience of the cohorts born from 1910 to 1970 . This period, especially since World War II, has witnessed profound changes in the time allocation of households with the spectacular increase in the labor force participation of married women (with children).

We have introduced two concepts of gender specialization in households and provided consistent estimators. Given the data restrictions our estimators can only identify the differential effect of parental education on the attainment of male and female children. In this respect our analysis complements a large literature that studies the effects of parental education but does not consider different roles of paternal and maternal education.

Our estimates show that paternal specialization (on sons) has been present in all cohorts since 1910 . However, maternal specialization (on daughters) seems to have appeared only for cohorts born after 1955. We interpret these results as supporting the view that fathers are more important role models for sons than for daughters and, conversely, mothers are a more important reference for daughters than for sons.

We have reasons to believe that both types of gender specialization may have been present all along, for cohorts born since 1910. Our argument is based on the effects of unobserved income on our estimators of gender specialization. Earlier cohorts might have experienced asymmetric educational investment patterns that would have discriminated against daughters, a situation virtually non-existent nowadays. In this respect, we believe that the estimates of gender specialization for the most recent cohorts are more trustworthy. To support this interpretation we have analyzed differences in gender specialization between two types of families: those with working mothers and those with non-working mothers. We have maintained the assumption that families with working mothers are characterized by smaller gender biases in the educational investment of children, due to the greater intra-household bargaining power of wage-earning mothers. We find that maternal (and paternal) specialization are present in families with working mothers but do not find it in the more 
traditional type of families. Additional evidence for our interpretation that gender specialization may have been present in households all along comes from analyzing the temporary surge in maternal employment in the US during World War II.

We are also aware that these pieces of evidence offer only partial confirmation of our interpretation. A more conclusive analysis would benefit from measures of family income for the families in all the cohorts analyzed. In that case, the bias introduced by asymmetric uses of family income in sons and daughters could be eliminated, which would surely clarify the analysis. We believe that our strategy may prove useful to the analysis of other questions with a long-run focus that face similar data constraints.

\section{References}

[1] Acemoglu, D., Angrist, J (2000). "How Large Are Human Capital Externalities? Evidence from Compulsory Schooling Laws,” NBER Macroeconomics annual 2000.

[2] Acemoglu, D., Autor, D., and D. Lyle (2004). "Women, War and Wages: The Effect of Female Labor Supply on the Wage Structure at Mid-Century," Journal of Political Economics, June, vol. $112,497-551$.

[3] Antonovics, K., Goldberger, A. (2005). "Does Increasing Women's Schooling Raise the Schooling of the Next Generation? - Comment," American Economic Review, Volume 95, Number 5, December, pp. 1738-1744(7).

[4] Behrman, J. R., and M. R. Rosenzweig (2002). "Does Increasing Women's Schooling Raise the Schooling of the Next Generation?," American Economic Review, March.

[5] Bernal, R. (2006). "The Effect of Maternal Employment and Child Care on Children's Cognitive Development," mimeo, Northwestern University.

[6] Black, S., Devereux, P., and Salvanes, K. (2005). "Why the Apple Doesn't Fall Far: Understanding Intergenerational Transmission of Human Capital." American Economic Review, March.

[7] Cameron, S. and Heckman, J. (2001). "The Dynamics of Educational Attainment for Blacks, Whites and Hispanics," Journal of Political Economy.

[8] Card, D. and T. Lemieux (2000). "Dropout and Enrollment Trends in the Post-War Period: What Went Wrong in the 1970s?" Forthcoming in Jonathan Gruber, editor, An Economic Analysis of Risky Behavior Among Youth. Chicago: University of Chicago Press. 
[9] Chevalier, A. (2000). Parental Education and Child's Education: A Natural Experiment. Center for the Economics of Education, London School of Economics.

[10] Currie, J. and E. Moretti (2003). "Mother's Education and the Intergenerational Transmission of Human Capital: Evidence from College Openings," Quarterly Journal of Economics.

[11] Fernández, R. and R. Rogerson (2001). “Sorting and Long-Run Inequality,” Quarterly Journal of Economics.

[12] Fernández, R., Fogli, A., and C. Olivetti (2002). "Marrying your mum: preference transmission and women's labor and education choices," mimeo, New York University.

[13] Goldberger, A. S. (1991). A Course in Econometrics, Harvard University Press.

[14] Goldin, C. (1990). Understanding the gender gap. An economic history of American women. Oxford University Press.

[15 ]Gregg, P., Washbrook, E., Propper, C., Burgess, S. (2005). “The effect of a mother's return to work decision on child development in the UK," The Economic Journal.

[16] Haveman, R. and B. Wolfe (1995). "The Determinants Of Children's Attainments: A Review Of Methods And Findings," Journal of Economic Literature.

[17] Keane, M. and K.Wolpin (2001). "The Effect of Parental Transfers and Borrowing Constraints on Educational Attainment," International Economic Review.

[18] Kremer, M. (1997). "How Much Does Sorting Increase Inequality?," Quarterly Journal of Economics.

[19] Leibowitz, A. (2003). "In-Home Training and the Production of Children's Human Capital," Review of Economics of the Household, 1, 305-317.

[20] Le, Anh, Miller, Paul, Heath, Andrew, and Nick Martin (2005). "Early Childhood Behaviors, Schooling and Labour Market Outcomes: Estimates from a Sample of Twins." Economics of Education Review, vol. 24, 1-17.

[21] Lundberg, S., and E. Rose (2002). "The Effects of Sons and Daughters on Men's Labor Supply and Wages," Review of Economics and Statistics, May.

[22] Mare, R. D. (1991). "Five Decades of Educational Assortative Mating," American Sociological Review.

[23] McGrattan, E., and R. Rogerson (1998). “Changes in Hours Worked since 1950,” Federal Reserve Bank of Minneapolis Quarterly Review.

[24] Millimet, D. (2000). "The Impact of Children on Wages, Job Tenure, and the Division of Household Labor," The Economic Journal. 
[25] Olivetti, C. (2006). "Changes in Women's Aggregate Hours of Work: The Role of Returns to Experience," Review of Economic Dynamics, 9, no. 4, October, 557-587.

[26] Pasqua, S. (2005). "Gender Bias in Parental Investments in Children's Education: A Theoretical Analysis," Review of Economics of the Household, 3, 291-314.

[27] Plug, E. (2002). "How Do Parents Raise the Educational Attainment of Future Generations?", IZA Discussion paper No. 652.

[28] Plug, E., Vijverger, W. (2005). "Does Family Income Matter for Schooling Outcomes? Using Adoption as A Natural Experiment," The Economic Journal.

[29] Raaum, O., Salvanes, K., Sorensen E. (2006). "The Neighborhood Is Not What It Used To Be," The Economic Journal.

[30] Tansel, Aysit (2002). "Determinants of School Attainment of Boys and Girls in Turkey: Individual, Household and Community Factors." Economics of Education Review, vol 21, 455-470.

[31] Thomas, D. (1990). "Intra-household Resource Allocation: An Inferential Approach," Journal of Human Resources, 25.4: 635-664.

[32] Thomas, D. (1994). "Like Father Like Son, or, Like Mother, Like Daughter: Parental Education and Child Health," Journal of Human Resources, 29.4: 950-988.

\section{Appendix}

\section{A}

\section{Sensitivity Analysis}

This section addresses some concerns about the robustness of the results reported above. Let us deal with them one by one.

\section{A.1 Data censoring}

We may be concerned that the drop in the weight of maternal education on sons's attainment might be the result of systematic differences in the age at interview of the respondents.

More specifically, the average age at the time of interview falls with the year of birth (see tables 1.1 and 1.2), increasing the possibility of "data censoring". That is, some individuals might have been interviewed before they completed their desired years of education. Coupled with the increasing average educational attainment of both parents throughout the time period considered, this aspect of the data collection might lead to artificially low estimated coefficients on parental education for the latest cohorts.

Tables 6.1 and 6.2 provide descriptive statistics for the sample of individuals of age 30 or above at 
the time of the interview. In order to assess the severity of the censoring problem we carry out the analysis using the subsample of individuals who were at least 30 years old at the time of the interview. Tables 7.1 and 7.2 present the results. Recall that in this sample the estimates have larger standard errors due to the lower number of observations, quite substantial for the cohorts born from 1955 onward (see tables 2.1 and 2.2).

The earlier results are largely confirmed. Figure 2.1 confirms our previous finding about the father's role. The father's education plays a larger role in the attainment of sons than in the attainment of daughters. On top of that, we find an upward trend in the father's coefficient, although for the current sample the increase is substantially larger on sons than on daughters.

Let us now turn to the mother's role. As figure 2.2 confirms, the maternal role is roughly constant for daughters but dramatically decreasing for sons, creating a gender gap for the cohorts born after 1955 .

A final argument that plays down the severity of the potential censoring problem is as follows. If data censoring were the driving reason behind our finding in the drop in the maternal role for sons, by the same argument, we should also find a similar drop in the paternal role too. However, the father's education in fact increases for the latest cohorts.

\section{A.2 Stagnation in the average educational attainment}

We may also be worried that the gender asymmetry that we found in the evolution of the maternal role for the cohorts born from the 1950s and onward is simply reflecting the trends in the average cohort attainment. More specifically, recall from tables 1.1 and 1.2 that the average (by cohort) years of education stagnated for the cohorts born in the 1950s. In addition, while the average only slowed down for women, it actually decreased for men. If we combine this fact with the on-trend growth in the educational attainment of the mothers of these cohorts, we might suspect that this is the origin of the gender asymmetric change in the maternal role. In this case, our findings should not be interpreted as changes in parental roles because they would not be the result of intra-household ties between parents and children, but rather the result of averages, that are totally unrelated to family ties.

However, this argument faces a serious objection. As can be seen in tables 1.1 and 1.2, the average years of paternal education have increased monotonically for all cohorts (just like the years of maternal education). As a result, the slowdown experienced by the cohorts born during the $1950 \mathrm{~s}$ should have also given rise to a gender asymmetry in the evolution of the father's role. That is, the coefficient on the father's education should have dropped for sons while being non-decreasing for daughters. However, figure 1.1 shows that this was not the case.

\section{B Chronology of female labor force participation}

This section aims at providing some background about when married women entered the labor market. We report two measures widely used in the literature: labor force participation rates and average hours worked (outside the home). As we shall see, both measures suggest the same timing of events. For our purposes, we wish to focus on younger wives (in the age bracket 25-34) since 
they are more likely to have young children.

Goldin (1990) has studied the evolution of female labor force participation in the United States. She concludes that the labor force participation of married women started to increase from 1920 and accelerated in the 1940s and beyond. Her analysis also reveals that while the expansion from the 1940 's to the 1960's was driven by married women older than 35, from the 1960's to the present, it was driven by the work of younger married women. Table 3.1 describes the evolution of the labor force participation rates for white married women in the age group 23-34, for a number of years. ${ }^{21}$ Observe the impressive increase that took place during the 1960s and 1970s.

Turning now to another measure of labor force participation, we borrow table 3.2 from McGrattan and Rogerson (1998). ${ }^{22}$ It contains the average weekly hours worked per person for married men and women in the 25-34 age bracket. ${ }^{23}$

It is worth noting that the data reported in the table are the result of two effects: the weekly hours per worker and the fraction of workers in the population. That is, the data above are consistent both with an increase in the number of employed married women (extensive margin) and with a constant number of employed married women that increased their hours of work (intensive margin).

In conclusion, work outside the house for married women with small children accelerated in 1960. Olivetti (2006) also makes this point and argues that it is the result of an increase in the returns to labor market experience for women.

Observe also that married men's labor force participation shows a slight decline over the time period considered, but it is very small relative to the changes in the labor force participation of married women.

21 This is a fragment of table 2.2 in Goldin (1990).

22 The data has been constructed by the authors using a number of waves of the U.S. Census. See their appendix for more details and a website to access their dataset.

${ }^{23}$ Source: McGrattan and Rogerson (1998), table 5. 
Figure 1.1: Marginal effect of paternal education (plus/minus one std.dev.)

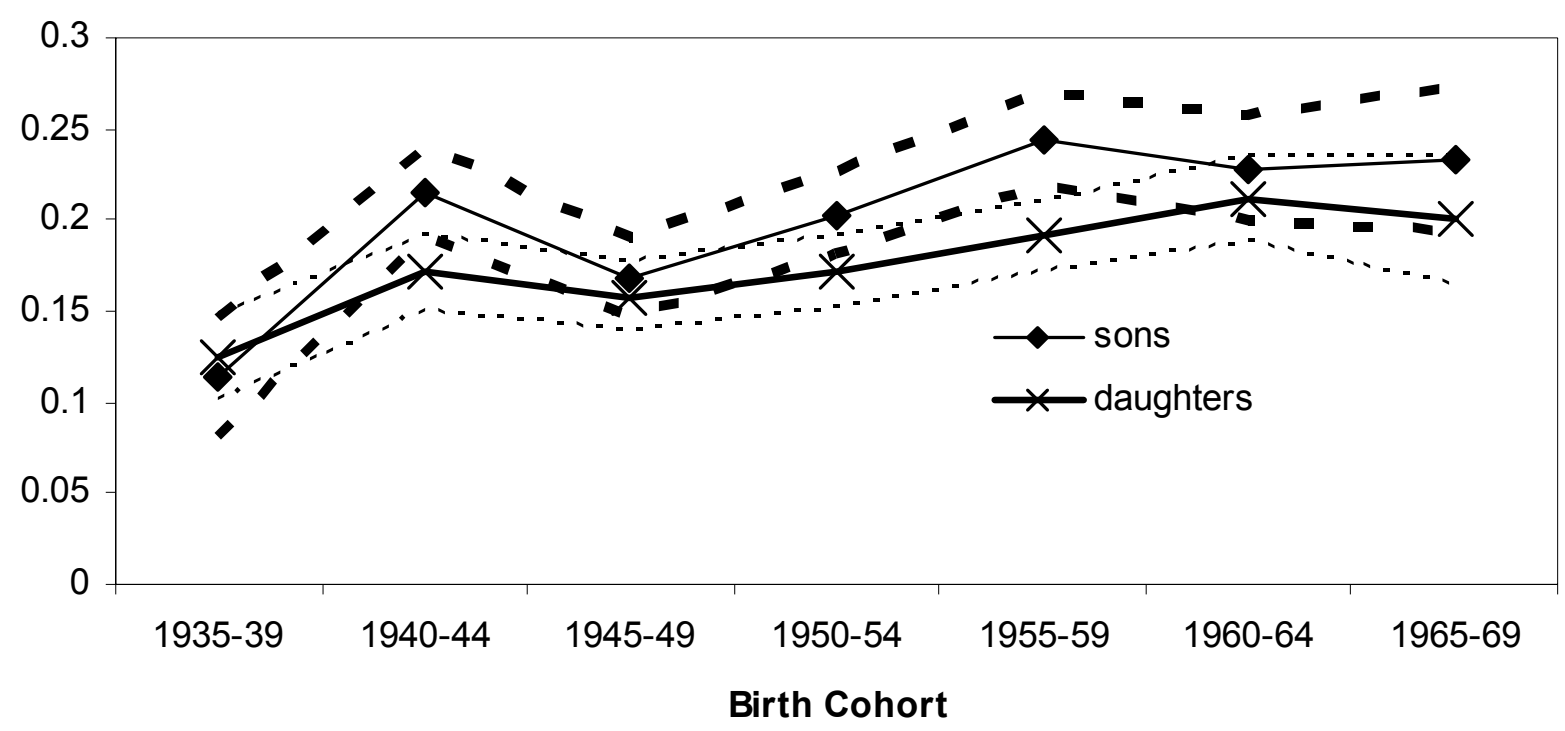

Figure 1.2: Marginal effect of $m$ aternal education (plus/minus one std.dev.)

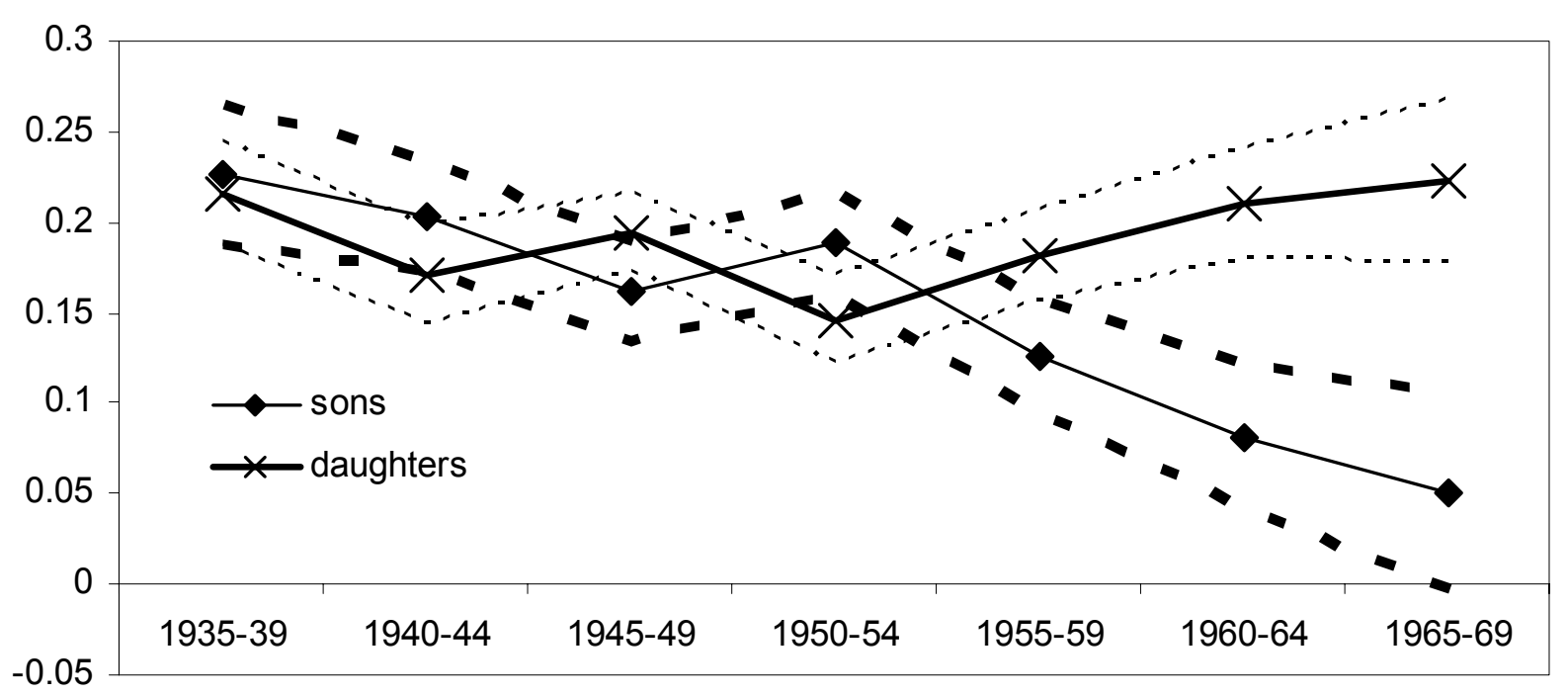

Birth Cohort 
Figure 1.3: Intercept

(plus/minus one std.dev.)

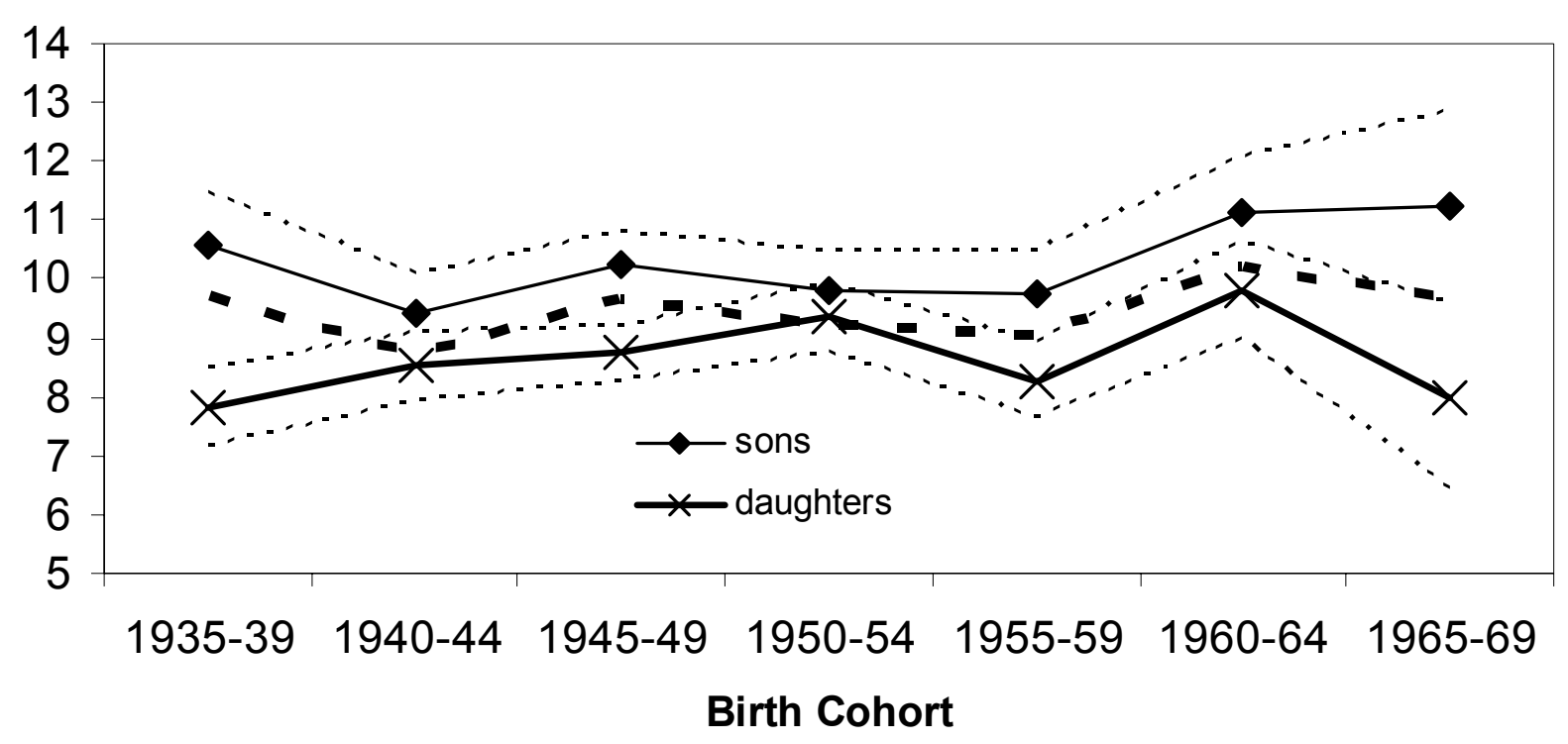

Figure 1.4: Gender Specialization (plus/minus one std.dev.)

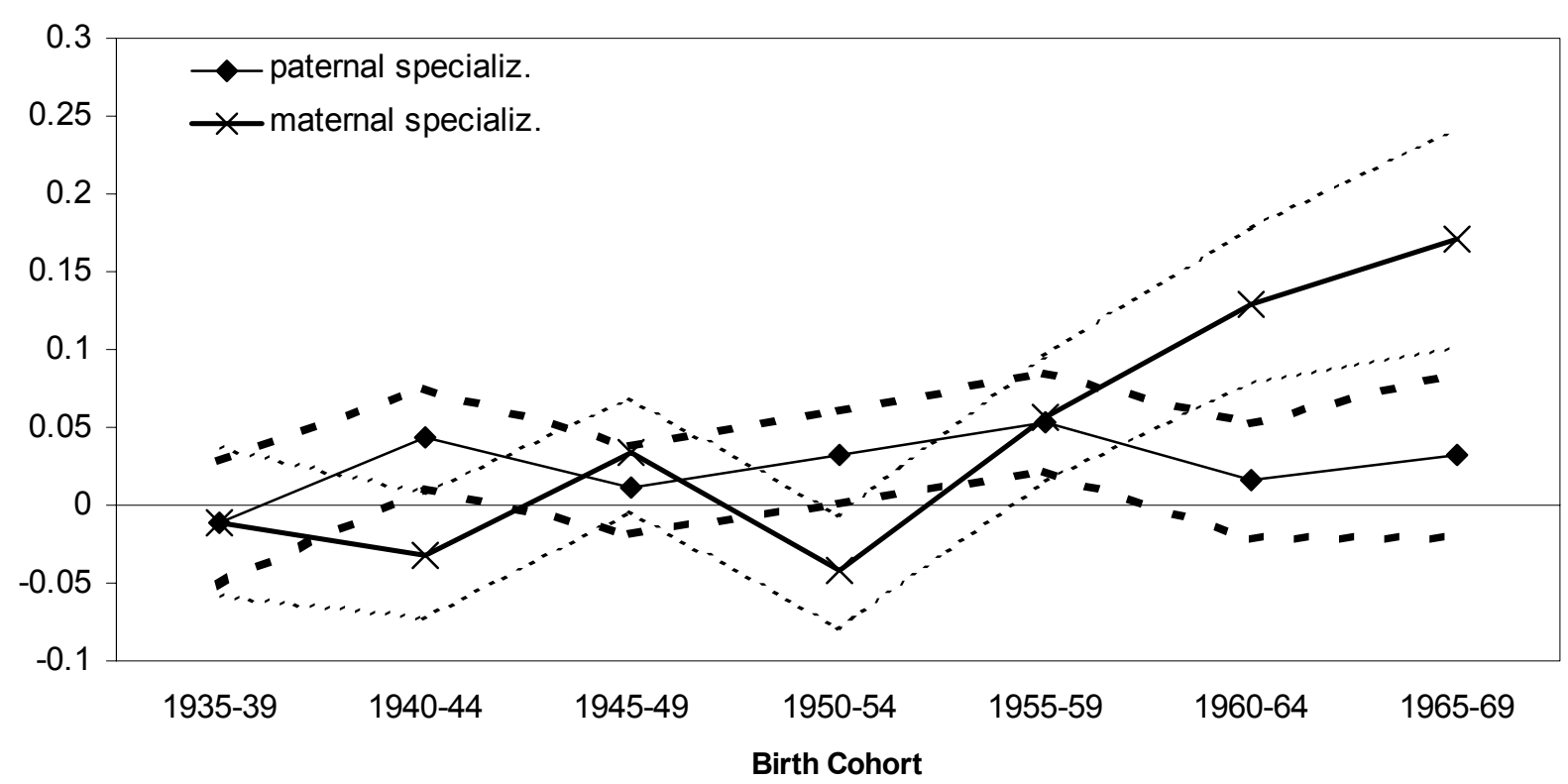


Figure 2.1: Marginal effe ct of paternal education (plus/minus one std.dev.)

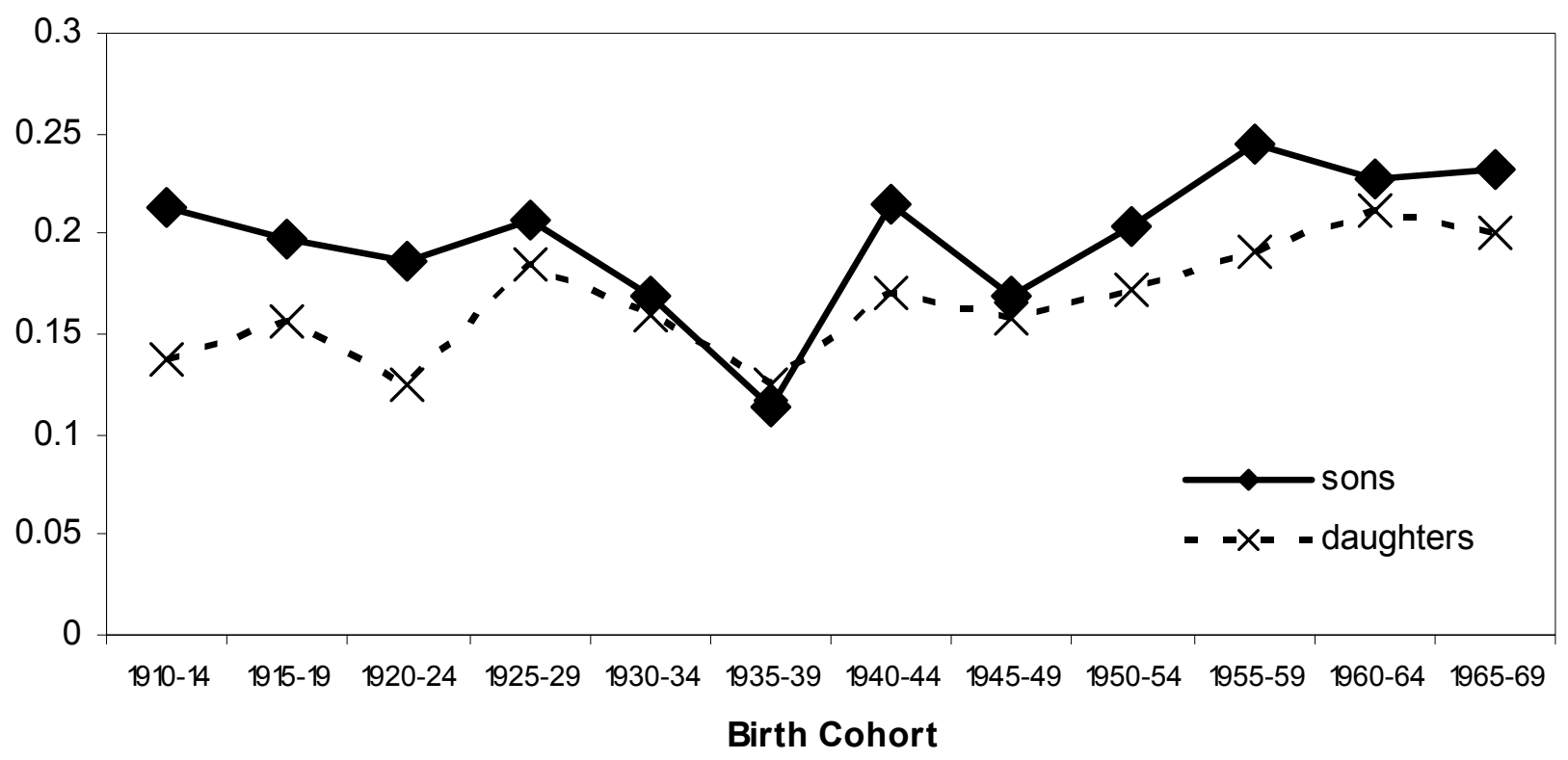

Figure 2.2: Marginal effect of $m$ aternal education (plus/minus one std.dev.)

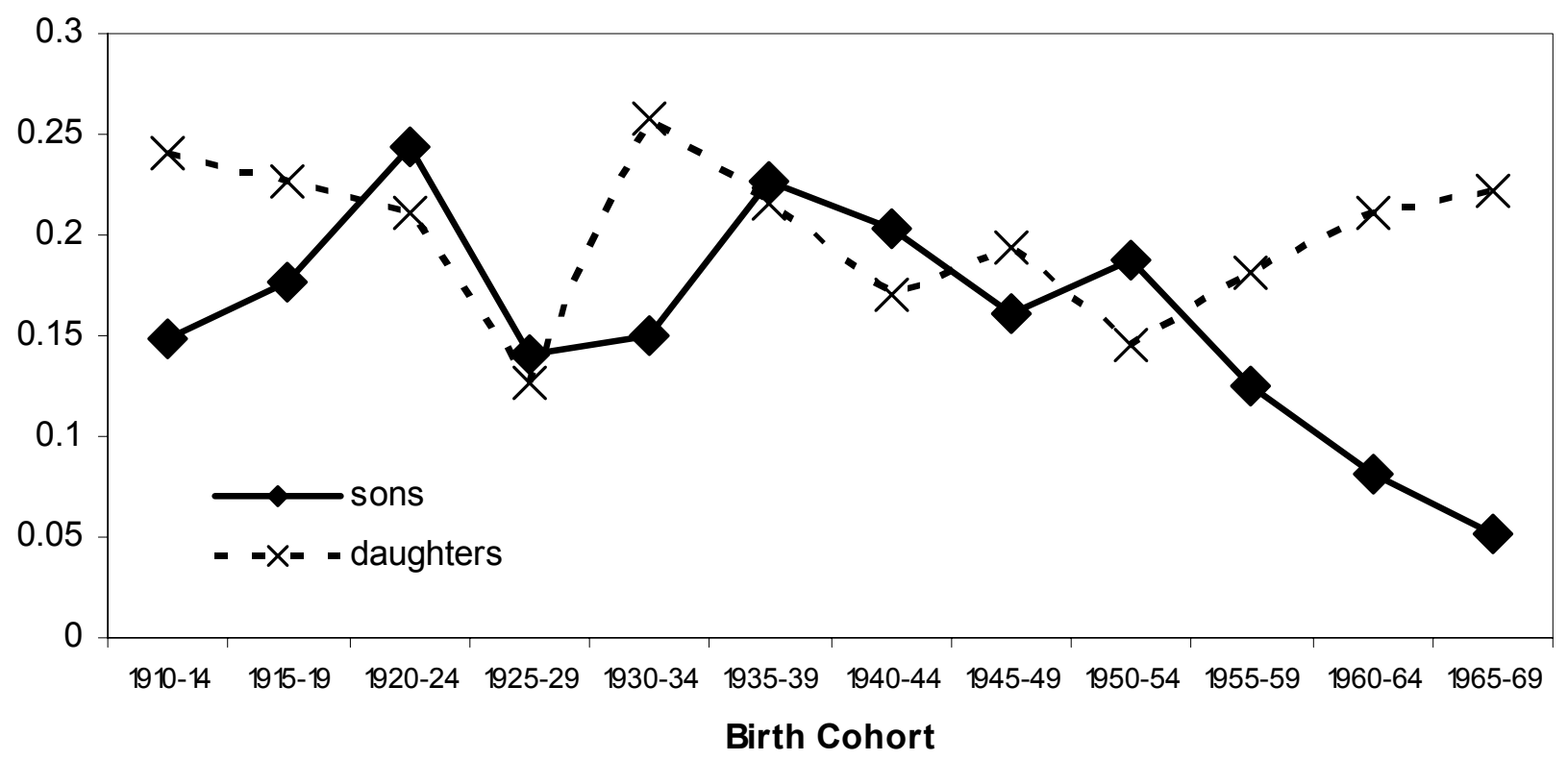


Figure 2.3: Intercept

(plus/minus one std.dev.)



Figure 2.4: Gender Specialization

(plus/minus one std.dev.)

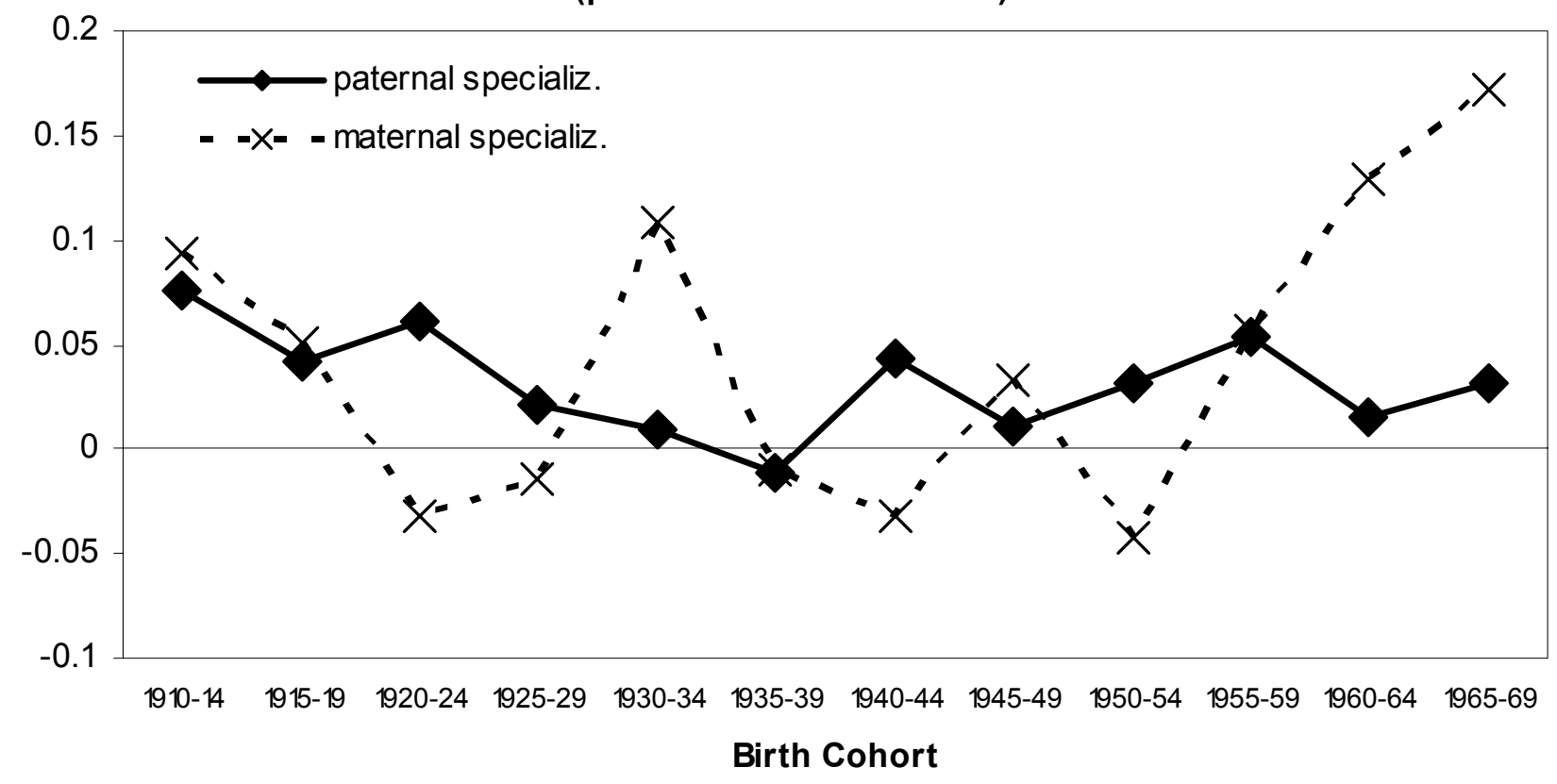


Table 1.1: Summary Characteristics by Cohort (Male, above 25)

\begin{tabular}{|c|c|c|c|c|c|c|c|}
\hline \multirow{2}{*}{$\begin{array}{l}\text { Variable } \\
\text { Birth Cohort }\end{array}$} & \multicolumn{7}{|c|}{$\begin{array}{l}\text { Sample Mean } \\
\text { Std. Dev. }\end{array}$} \\
\hline & 1935-39 & $1940-44$ & $1945-49$ & $1950-54$ & $1955-59$ & $1960-64$ & $1965-69$ \\
\hline No. observations & 814 & 1047 & 1364 & 1169 & 1027 & 684 & 355 \\
\hline $\mathrm{AGE}$ & $\begin{array}{c}46.40 \\
8.20\end{array}$ & $\begin{array}{l}41.93 \\
8.13\end{array}$ & $\begin{array}{c}37.98 \\
7.90\end{array}$ & $\begin{array}{r}35.71 \\
6.37\end{array}$ & $\begin{array}{c}33.24 \\
5.14\end{array}$ & $\begin{array}{c}30.92 \\
3.81\end{array}$ & $\begin{array}{r}28.47 \\
2.43\end{array}$ \\
\hline EDUC & $\begin{array}{c}13.32 \\
3.20\end{array}$ & $\begin{array}{c}13.81 \\
3.15\end{array}$ & $\begin{array}{c}14.20 \\
2.91\end{array}$ & $\begin{array}{c}14.15 \\
2.70\end{array}$ & $\begin{array}{l}13.88 \\
2.72\end{array}$ & $\begin{array}{c}14.02 \\
2.44\end{array}$ & $\begin{array}{c}14.10 \\
2.43\end{array}$ \\
\hline PAEDUC & $\begin{array}{l}9.31 \\
4.14\end{array}$ & $\begin{array}{c}10.16 \\
4.04\end{array}$ & $\begin{array}{c}10.75 \\
3.95\end{array}$ & $\begin{array}{c}11.49 \\
3.89\end{array}$ & $\begin{array}{c}11.99 \\
3.88\end{array}$ & $\begin{array}{c}12.40 \\
3.69\end{array}$ & $\begin{array}{c}12.82 \\
3.57\end{array}$ \\
\hline MAEDUC & $\begin{array}{c}10.06 \\
3.46\end{array}$ & $\begin{array}{c}10.76 \\
3.38\end{array}$ & $\begin{array}{c}11.03 \\
3.05\end{array}$ & $\begin{array}{c}11.58 \\
3.12\end{array}$ & $\begin{array}{c}11.96 \\
3.10\end{array}$ & $\begin{array}{c}12.20 \\
2.81\end{array}$ & $\begin{array}{l}12.57 \\
2.64\end{array}$ \\
\hline SIBS & $\begin{array}{l}3.55 \\
3.07\end{array}$ & $\begin{array}{l}3.30 \\
2.71\end{array}$ & $\begin{array}{l}3.37 \\
2.70\end{array}$ & $\begin{array}{l}3.44 \\
2.66\end{array}$ & $\begin{array}{l}3.51 \\
2.37\end{array}$ & $\begin{array}{l}3.31 \\
2.20\end{array}$ & $\begin{array}{l}2.98 \\
2.43\end{array}$ \\
\hline BLACK & 0.091 & 0.083 & 0.075 & 0.080 & 0.086 & 0.083 & 0.079 \\
\hline $\begin{array}{l}\text { PROTESTANT } \\
\text { CATHOLIC } \\
\text { JEWISH }\end{array}$ & $\begin{array}{l}0.628 \\
0.248 \\
0.020\end{array}$ & $\begin{array}{l}0.614 \\
0.246 \\
0.030\end{array}$ & $\begin{array}{l}0.583 \\
0.304 \\
0.026\end{array}$ & $\begin{array}{l}0.583 \\
0.328 \\
0.025\end{array}$ & $\begin{array}{l}0.549 \\
0.347 \\
0.026\end{array}$ & $\begin{array}{l}0.547 \\
0.339 \\
0.007\end{array}$ & $\begin{array}{l}0.524 \\
0.355 \\
0.017\end{array}$ \\
\hline $\begin{array}{l}\text { COUNTRY } \\
\text { FARM } \\
\text { SMALL TOWN } \\
\text { MID CITY } \\
\text { SUB CITY } \\
\text { LARGE CITY }\end{array}$ & $\begin{array}{l}0.128 \\
0.208 \\
0.312 \\
0.117 \\
0.080 \\
0.156\end{array}$ & $\begin{array}{l}0.102 \\
0.185 \\
0.309 \\
0.138 \\
0.121 \\
0.143\end{array}$ & $\begin{array}{l}0.101 \\
0.140 \\
0.325 \\
0.163 \\
0.130 \\
0.141\end{array}$ & $\begin{array}{l}0.116 \\
0.111 \\
0.314 \\
0.166 \\
0.150 \\
0.143\end{array}$ & $\begin{array}{l}0.121 \\
0.125 \\
0.303 \\
0.145 \\
0.184 \\
0.123\end{array}$ & $\begin{array}{l}0.145 \\
0.098 \\
0.287 \\
0.146 \\
0.190 \\
0.135\end{array}$ & $\begin{array}{l}0.132 \\
0.073 \\
0.330 \\
0.183 \\
0.152 \\
0.130\end{array}$ \\
\hline $\begin{array}{l}\text { NEW ENGLAND } \\
\text { MID. ATLANTIC } \\
\text { E.N. CENTRAL } \\
\text { W.N. CENTRAL } \\
\text { S. ATLANTIC } \\
\text { E.S. CENTRAL } \\
\text { W.S. CENTRAL } \\
\text { MOUNTAIN } \\
\text { PACIFIC } \\
\text { FOREIGN }\end{array}$ & $\begin{array}{l}0.048 \\
0.167 \\
0.177 \\
0.115 \\
0.149 \\
0.076 \\
0.090 \\
0.036 \\
0.098 \\
0.001\end{array}$ & $\begin{array}{l}0.043 \\
0.165 \\
0.218 \\
0.076 \\
0.152 \\
0.078 \\
0.078 \\
0.040 \\
0.099 \\
0.001\end{array}$ & $\begin{array}{l}0.045 \\
0.180 \\
0.224 \\
0.080 \\
0.145 \\
0.055 \\
0.078 \\
0.045 \\
0.100 \\
0.001\end{array}$ & $\begin{array}{l}0.047 \\
0.169 \\
0.225 \\
0.087 \\
0.128 \\
0.062 \\
0.071 \\
0.045 \\
0.107 \\
0.008\end{array}$ & $\begin{array}{l}0.051 \\
0.153 \\
0.222 \\
0.089 \\
0.133 \\
0.054 \\
0.071 \\
0.053 \\
0.118 \\
0.007\end{array}$ & $\begin{array}{l}0.063 \\
0.133 \\
0.211 \\
0.076 \\
0.146 \\
0.047 \\
0.089 \\
0.050 \\
0.115 \\
0.010\end{array}$ & $\begin{array}{l}0.065 \\
0.113 \\
0.194 \\
0.079 \\
0.146 \\
0.070 \\
0.101 \\
0.042 \\
0.101 \\
0.025\end{array}$ \\
\hline $\begin{array}{l}\text { Corr(EDUC,PAEDUC) } \\
\text { Corr(EDUC,MAEDUC) }\end{array}$ & $\begin{array}{l}0.412 \\
0.429\end{array}$ & $\begin{array}{l}0.492 \\
0.452\end{array}$ & $\begin{array}{l}0.409 \\
0.378\end{array}$ & $\begin{array}{l}0.466 \\
0.412\end{array}$ & $\begin{array}{l}0.485 \\
0.396\end{array}$ & $\begin{array}{l}0.414 \\
0.292\end{array}$ & $\begin{array}{l}0.460 \\
0.304\end{array}$ \\
\hline Corr(PAEDUC, MAEDUC) & 0.649 & 0.592 & 0.572 & 0.582 & 0.639 & 0.606 & 0.561 \\
\hline
\end{tabular}


Table 1.2: Summary Characteristics by Cohort (Female, above 25)

\begin{tabular}{|c|c|c|c|c|c|c|c|}
\hline Variable & & & & $\begin{array}{l}\text { mple Mea } \\
\text { Std. Dev. }\end{array}$ & & & \\
\hline Birth Cohort & $1935-39$ & $1940-44$ & $1945-49$ & $1950-54$ & $1955-59$ & $1960-64$ & $1965-69$ \\
\hline No. observations & 957 & 1283 & 1588 & 1420 & 1311 & 812 & 411 \\
\hline $\mathrm{AGE}$ & $\begin{array}{c}46.60 \\
8.18\end{array}$ & $\begin{array}{l}42.38 \\
8.24\end{array}$ & $\begin{array}{c}37.83 \\
7.95\end{array}$ & $\begin{array}{c}35.70 \\
6.23\end{array}$ & $\begin{array}{c}32.93 \\
5.11\end{array}$ & $\begin{array}{c}30.72 \\
3.75\end{array}$ & $\begin{array}{c}28.45 \\
2.35\end{array}$ \\
\hline EDUC & $\begin{array}{c}12.72 \\
2.60\end{array}$ & $\begin{array}{c}13.24 \\
2.70\end{array}$ & $\begin{array}{c}13.62 \\
2.57\end{array}$ & $\begin{array}{c}13.73 \\
2.51\end{array}$ & $\begin{array}{c}13.87 \\
2.47\end{array}$ & $\begin{array}{c}13.88 \\
2.45\end{array}$ & $\begin{array}{c}14.06 \\
2.44\end{array}$ \\
\hline PAEDUC & $\begin{array}{l}9.31 \\
3.86\end{array}$ & $\begin{array}{c}10.07 \\
4.09\end{array}$ & $\begin{array}{c}10.64 \\
3.86\end{array}$ & $\begin{array}{c}10.94 \\
3.89\end{array}$ & $\begin{array}{c}11.89 \\
3.97\end{array}$ & $\begin{array}{c}12.22 \\
3.85\end{array}$ & $\begin{array}{c}12.80 \\
3.77\end{array}$ \\
\hline MAEDUC & $\begin{array}{l}9.89 \\
3.28\end{array}$ & $\begin{array}{c}10.45 \\
3.29\end{array}$ & $\begin{array}{c}10.98 \\
3.26\end{array}$ & $\begin{array}{c}11.19 \\
3.12\end{array}$ & $\begin{array}{c}11.84 \\
3.09\end{array}$ & $\begin{array}{c}12.17 \\
2.93\end{array}$ & $\begin{array}{c}12.68 \\
2.98\end{array}$ \\
\hline SIBS & $\begin{array}{l}3.84 \\
3.20\end{array}$ & $\begin{array}{l}3.59 \\
2.95\end{array}$ & $\begin{array}{l}3.59 \\
2.87\end{array}$ & $\begin{array}{l}3.71 \\
2.74\end{array}$ & $\begin{array}{l}3.73 \\
2.76\end{array}$ & $\begin{array}{l}3.55 \\
2.53\end{array}$ & $\begin{array}{l}3.04 \\
2.33\end{array}$ \\
\hline BLACK & 0.090 & 0.104 & 0.111 & 0.127 & 0.111 & 0.115 & 0.102 \\
\hline $\begin{array}{l}\text { PROTESTANT } \\
\text { CATHOLIC }\end{array}$ & $\begin{array}{l}0.652 \\
0.254\end{array}$ & $\begin{array}{l}0.635 \\
0.256\end{array}$ & $\begin{array}{l}0.609 \\
0.302\end{array}$ & $\begin{array}{l}0.630 \\
0.295\end{array}$ & $\begin{array}{l}0.576 \\
0.357\end{array}$ & $\begin{array}{l}0.570 \\
0.337\end{array}$ & $\begin{array}{l}0.545 \\
0.319\end{array}$ \\
\hline JEWISH & 0.018 & 0.021 & 0.022 & 0.023 & 0.025 & 0.014 & 0.019 \\
\hline COUNTRY & 0.126 & 0.111 & 0.121 & 0.103 & 0.123 & 0.139 & 0.114 \\
\hline FARM & 0.195 & 0.152 & 0.119 & 0.113 & 0.085 & 0.086 & 0.080 \\
\hline SMALL TOWN & 0.317 & 0.332 & 0.312 & 0.320 & 0.300 & 0.303 & 0.326 \\
\hline MID CITY & 0.131 & 0.155 & 0.156 & 0.171 & 0.188 & 0.172 & 0.190 \\
\hline SUB CITY & 0.083 & 0.108 & 0.139 & 0.137 & 0.173 & 0.158 & 0.161 \\
\hline LARGE CITY & 0.148 & 0.143 & 0.153 & 0.156 & 0.131 & 0.142 & 0.129 \\
\hline NEW ENGLAND & 0.059 & 0.044 & 0.050 & 0.044 & 0.054 & 0.047 & 0.054 \\
\hline MID. ATLANTIC & 0.171 & 0.162 & 0.178 & 0.154 & 0.163 & 0.166 & 0.095 \\
\hline E.N. CENTRAL & 0.203 & 0.210 & 0.197 & 0.206 & 0.217 & 0.211 & 0.195 \\
\hline W.N. CENTRAL & 0.096 & 0.092 & 0.079 & 0.085 & 0.081 & 0.075 & 0.100 \\
\hline S. ATLANTIC & 0.149 & 0.140 & 0.141 & 0.151 & 0.133 & 0.137 & 0.134 \\
\hline E.S. CENTRAL & 0.072 & 0.074 & 0.075 & 0.071 & 0.059 & 0.052 & 0.063 \\
\hline W.S. CENTRAL & 0.084 & 0.094 & 0.088 & 0.083 & 0.076 & 0.078 & 0.102 \\
\hline MOUNTAIN & 0.042 & 0.038 & 0.039 & 0.042 & 0.053 & 0.054 & 0.071 \\
\hline PACIFIC & 0.066 & 0.100 & 0.105 & 0.113 & 0.120 & 0.123 & 0.124 \\
\hline FOREIGN & 0.006 & 0.003 & 0.006 & 0.007 & 0.008 & 0.017 & 0.029 \\
\hline Corr(EDUC,PAEDUC) & 0.396 & 0.441 & 0.450 & 0.422 & 0.460 & 0.489 & 0.481 \\
\hline Corr(EDUC,MAEDUC) & 0.440 & 0.429 & 0.441 & 0.371 & 0.425 & 0.445 & 0.449 \\
\hline Corr(PAEDUC,MAEDUC) & 0.588 & 0.620 & 0.594 & 0.611 & 0.601 & 0.551 & 0.573 \\
\hline
\end{tabular}


Table 2.1: Roles of Parents' Education by Cohort (Male, above 25)

\begin{tabular}{|c|c|c|c|c|c|c|c|c|c|c|c|c|c|c|}
\hline \multirow{3}{*}{$\begin{array}{l}\text { Birth Cohort } \\
\text { PAEDUC }\end{array}$} & \multirow{2}{*}{\multicolumn{2}{|c|}{$1935-39$}} & \multirow{2}{*}{\multicolumn{2}{|c|}{$1940-44$}} & \multicolumn{6}{|c|}{ Dependent varlable is EDUC } & \multirow{2}{*}{\multicolumn{2}{|c|}{$1960-64$}} & \multirow{2}{*}{\multicolumn{2}{|c|}{$1965-69$}} \\
\hline & & & & & $1945-49$ & & $1950-54$ & & $1955-59$ & & & & & \\
\hline & $\begin{array}{l}0.114 \\
0.032\end{array}$ & $\cdots *$ & $\begin{array}{l}0.214 \\
0.025\end{array}$ & $* * *$ & $\begin{array}{l}0.170 \\
0.022\end{array}$ & $* *$ & $\begin{array}{l}0.204 \\
0.023\end{array}$ & $* *$ & $\begin{array}{l}0.243 \\
0.025\end{array}$ & $* *$ & $\begin{array}{l}0.228 \\
0.029\end{array}$ & $* * *$ & $\begin{array}{l}0.233 \\
0.040\end{array}$ & $* *$ \\
\hline MAEDUC & $\begin{array}{l}0.225 \\
0.039\end{array}$ & $\cdots$ & $\begin{array}{l}0.203 \\
0.031\end{array}$ & $* *$ & $\begin{array}{l}0.160 \\
0.029\end{array}$ & $* *$ & $\begin{array}{l}0.187 \\
0.028\end{array}$ & $* *$ & $\begin{array}{l}0.127 \\
0.032\end{array}$ & $* *$ & $\begin{array}{l}0.085 \\
0.039\end{array}$ & $*$ & $\begin{array}{l}0.051 \\
0.054\end{array}$ & \\
\hline AGE & $\begin{array}{l}0.025 \\
0.012\end{array}$ & $*$ & $\begin{array}{l}0.027 \\
0.010\end{array}$ & $* * *$ & $\begin{array}{l}0.027 \\
0.009\end{array}$ & $* * *$ & $\begin{array}{l}0.026 \\
0.011\end{array}$ & $*$ & $\begin{array}{l}0.050 \\
0.014\end{array}$ & $\cdots$ & $\begin{array}{l}0.011 \\
0.022\end{array}$ & & $\begin{array}{r}-0.004 \\
0.047\end{array}$ & \\
\hline SIBS & $\begin{array}{l}-0.163 \\
0.035\end{array}$ & $\cdots$ & $\begin{array}{l}-0.121 \\
0.033\end{array}$ & $* *$ & $\begin{array}{l}-0.180 \\
0.028\end{array}$ & $* * *$ & $\begin{array}{c}-0.090 \\
0.028\end{array}$ & $* *$ & $\begin{array}{r}-0.137 \\
0.033\end{array}$ & $* *$ & $\begin{array}{c}-0.065 \\
0.041\end{array}$ & & $\begin{array}{r}-0.138 \\
0.050\end{array}$ & $\cdots$ \\
\hline BLACK & $\begin{array}{l}-0.455 \\
0.359\end{array}$ & & $\begin{array}{l}-0.368 \\
0.311\end{array}$ & & $\begin{array}{l}0.148 \\
0.279\end{array}$ & & $\begin{array}{l}-0.183 \\
0.272\end{array}$ & & $\begin{array}{l}-0.022 \\
0.277\end{array}$ & & $\begin{array}{l}-0.249 \\
0.318\end{array}$ & & $\begin{array}{r}-0.185 \\
0.436\end{array}$ & \\
\hline PROTESTANT & $\begin{array}{l}-0.592 \\
0.348\end{array}$ & $\cdot$ & $\begin{array}{l}-0.221 \\
0.283\end{array}$ & & $\begin{array}{l}-0.411 \\
0.261\end{array}$ & & $\begin{array}{c}-0.310 \\
0.308\end{array}$ & & $\begin{array}{l}-0.212 \\
0.293\end{array}$ & & $\begin{array}{r}-0.257 \\
0.301\end{array}$ & & $\begin{array}{l}0.107 \\
0.412\end{array}$ & \\
\hline CATHOLIC & $\begin{array}{l}-0.786 \\
0.370\end{array}$ & $*$ & $\begin{array}{l}-0.165 \\
0.302\end{array}$ & & $\begin{array}{l}-0.138 \\
0.271\end{array}$ & & $\begin{array}{l}-0.125 \\
0.314\end{array}$ & & $\begin{array}{l}0.129 \\
0.299\end{array}$ & & $\begin{array}{r}-0.017 \\
0.303\end{array}$ & & $\begin{array}{l}0.062 \\
0.405\end{array}$ & \\
\hline JEWISH & $\begin{array}{l}0.750 \\
0.768\end{array}$ & & $\begin{array}{l}2.084 \\
0.5388\end{array}$ & $* * *$ & $\begin{array}{l}1.192 \\
0.490\end{array}$ & $* *$ & $\begin{array}{l}0.717 \\
0.534\end{array}$ & & $\begin{array}{l}0.484 \\
0.535\end{array}$ & & $\begin{array}{l}0.397 \\
1.018\end{array}$ & & $\begin{array}{l}2.953 \\
0.947\end{array}$ & $\cdots$ \\
\hline FARM & $\begin{array}{l}0.211 \\
0.350\end{array}$ & & $\begin{array}{l}-0.106 \\
0.317\end{array}$ & & $\begin{array}{l}0.144 \\
0.285\end{array}$ & & $\begin{array}{l}-0.142 \\
0.288\end{array}$ & & $\begin{array}{l}-0.027 \\
0.296\end{array}$ & & $\begin{array}{l}0.272 \\
0.347\end{array}$ & & $\begin{array}{l}-0.050 \\
0.526\end{array}$ & \\
\hline SMALL TOWN & $\begin{array}{l}0.438 \\
0.323\end{array}$ & & $\begin{array}{l}0.586 \\
0.250\end{array}$ & $* *$ & $\begin{array}{l}0.638 \\
0.249\end{array}$ & $*$ & $\begin{array}{l}0.233 \\
0.236\end{array}$ & & $\begin{array}{l}0.333 \\
0.249\end{array}$ & & $\begin{array}{l}0.784 \\
0.270\end{array}$ & $* * *$ & $\begin{array}{l}0.690 \\
0.373\end{array}$ & $\cdot$ \\
\hline MID CITY & $\begin{array}{l}1.265 \\
0.402\end{array}$ & $* *$ & $\begin{array}{l}0.804 \\
0.336\end{array}$ & $*$ & $\begin{array}{l}0.710 \\
0.279\end{array}$ & $*$ & $\begin{array}{l}0.060 \\
0.266\end{array}$ & & $\begin{array}{l}0.581 \\
0.289\end{array}$ & $*$ & $\begin{array}{l}0.415 \\
0.318\end{array}$ & & $\begin{array}{l}0.572 \\
0.408\end{array}$ & \\
\hline SUB CITY & $\begin{array}{l}0.949 \\
0.452\end{array}$ & $*$ & $\begin{array}{l}0.619 \\
0.348\end{array}$ & $\cdot$ & $\begin{array}{l}0.858 \\
0.297\end{array}$ & $* * *$ & $\begin{array}{l}0.530 \\
0.274\end{array}$ & $\cdot$ & $\begin{array}{l}0.463 \\
0.274\end{array}$ & • & $\begin{array}{l}0.850 \\
0.300\end{array}$ & $* *$ & $\begin{array}{l}1.285 \\
0.430\end{array}$ & $* *$ \\
\hline LARGE CITY & $\begin{array}{l}0.899 \\
0.387\end{array}$ & $*$ & $\begin{array}{l}0.531 \\
0.337\end{array}$ & & $\begin{array}{l}0.758 \\
0.293\end{array}$ & $* * *$ & $\begin{array}{l}0.504 \\
0.279\end{array}$ & * & $\begin{array}{l}0.783 \\
0.305\end{array}$ & $* *$ & $\begin{array}{l}1.047 \\
0.330\end{array}$ & $* *$ & $\begin{array}{l}0.481 \\
0.455\end{array}$ & \\
\hline NEW ENGLAND & $\begin{array}{l}0.418 \\
0.658\end{array}$ & & $\begin{array}{l}-0.311 \\
0.536\end{array}$ & & $\begin{array}{l}0.099 \\
0.460\end{array}$ & & $\begin{array}{l}-1.116 \\
0.444\end{array}$ & $*$ & $\begin{array}{l}-1.164 \\
0.460\end{array}$ & $* *$ & $\begin{array}{r}-1.473 \\
0.494\end{array}$ & $* *$ & $\begin{array}{r}-0.915 \\
0.613\end{array}$ & \\
\hline MID. ATLANTIC & $\begin{array}{l}0.157 \\
0.540\end{array}$ & & $\begin{array}{r}-1.247 \\
0.423\end{array}$ & $* * *$ & $\begin{array}{l}-0.466 \\
0.365\end{array}$ & & $\begin{array}{r}-0.977 \\
0.353\end{array}$ & $* *$ & $\begin{array}{l}-0.960 \\
0.377\end{array}$ & $*$ & $\begin{array}{r}-1.330 \\
0.420\end{array}$ & $* * *$ & $\begin{array}{r}-0.463 \\
0.522\end{array}$ & \\
\hline E.N. CENTRAL & $\begin{array}{l}-0.259 \\
0.535\end{array}$ & & $\begin{array}{c}-1.103 \\
0.412\end{array}$ & $* *$ & $\begin{array}{l}-0.470 \\
0.358\end{array}$ & & $\begin{array}{l}-1.170 \\
0.34 I\end{array}$ & $\cdots *$ & $\begin{array}{l}-1.145 \\
0.359\end{array}$ & $* *$ & $\begin{array}{r}-1.504 \\
0.393\end{array}$ & $* *$ & $\begin{array}{l}-0.307 \\
0.471\end{array}$ & \\
\hline W.N. CENTRAL & $\begin{array}{l}-0.260 \\
0.570\end{array}$ & & $\begin{array}{l}-0.696 \\
0.481\end{array}$ & & $\begin{array}{l}-0.370 \\
0.411\end{array}$ & & $\begin{array}{r}-1.015 \\
0.387\end{array}$ & $* *$ & $\begin{array}{l}-0.958 \\
0.41 I\end{array}$ & $*$ & $\begin{array}{r}-0.935 \\
0.466\end{array}$ & $*$ & $\begin{array}{l}0.942 \\
0.576\end{array}$ & \\
\hline S. ATL.ANTIC & $\begin{array}{l}-0.635 \\
0.558\end{array}$ & & $\begin{array}{c}-1.364 \\
0.432\end{array}$ & $* * *$ & $\begin{array}{l}-0.790 \\
0.376\end{array}$ & $*$ & $\begin{array}{c}-0.939 \\
0.371\end{array}$ & $*$ & $\begin{array}{r}-1.165 \\
0.384\end{array}$ & $* *$ & $\begin{array}{r}-1.259 \\
0.424\end{array}$ & $* * *$ & $\begin{array}{r}-0.902 \\
0.503\end{array}$ & $\cdot$ \\
\hline E.S. CENTRAL & $\begin{array}{l}-0.139 \\
0.6055\end{array}$ & & $\begin{array}{c}-1.210 \\
0.482\end{array}$ & $*$ & $\begin{array}{c}-0.778 \\
0.450\end{array}$ & * & $\begin{array}{l}-0.850 \\
0.422\end{array}$ & $*$ & $\begin{array}{l}-0.935 \\
0.453\end{array}$ & $*$ & $\begin{array}{r}-2.291 \\
0.530\end{array}$ & $* * *$ & $\begin{array}{l}-0.622 \\
0.606\end{array}$ & \\
\hline W.S. CENTRAL & $\begin{array}{l}-0.451 \\
0.580\end{array}$ & & $\begin{array}{l}-0.473 \\
0.472\end{array}$ & & $\begin{array}{l}-0.340 \\
0.409\end{array}$ & & $\begin{array}{l}-0.858 \\
0.40 I\end{array}$ & $*$ & $\begin{array}{l}-0.720 \\
0.422\end{array}$ & $\cdot$ & $\begin{array}{r}-1.511 \\
0.450\end{array}$ & $* * *$ & $\begin{array}{l}-0.508 \\
0.531\end{array}$ & \\
\hline MOUNTAIN & $\begin{array}{l}0.492 \\
0.710\end{array}$ & & $\begin{array}{c}-1.276 \\
0.546\end{array}$ & $* *$ & $\begin{array}{l}0.281 \\
0.460\end{array}$ & & $\begin{array}{l}-0.630 \\
0.44 I\end{array}$ & & $\begin{array}{l}-1.226 \\
0.455\end{array}$ & $* *$ & $\begin{array}{l}-0.728 \\
0.514\end{array}$ & & $\begin{array}{r}-0.820 \\
0.665\end{array}$ & \\
\hline PACIFIC & $\begin{array}{l}-0.137 \\
0.576\end{array}$ & & $\begin{array}{l}-0.624 \\
0.451\end{array}$ & & $\begin{array}{l}-0.285 \\
0.391\end{array}$ & & $\begin{array}{l}-0.902 \\
0.371\end{array}$ & $*$ & $\begin{array}{r}-1.328 \\
0.384\end{array}$ & $* *$ & $\begin{array}{r}-1.695 \\
0.433\end{array}$ & $* * *$ & $\begin{array}{l}-0.997 \\
0.531\end{array}$ & $\cdot$ \\
\hline Constant & $\begin{array}{l}9.616 \\
0.833\end{array}$ & $* *$ & $\begin{array}{l}9.410 \\
0.688\end{array}$ & $* * *$ & $\begin{array}{c}10.289 \\
0.593\end{array}$ & $* * *$ & $\begin{array}{l}9.934 \\
0.631\end{array}$ & $* *$ & $\begin{array}{l}9.010 \\
0.703\end{array}$ & $* *$ & $\begin{array}{c}10.895 \\
0.913\end{array}$ & $* * *$ & $\begin{array}{c}10.752 \\
1.577\end{array}$ & $* *$ \\
\hline Observations & 814 & & 1047 & & 1364 & & 1169 & & 1027 & & 684 & & 355 & \\
\hline R-squared & 0.28 & & 0.35 & & 0.27 & & 0.28 & & 0.3 & & 0.24 & & 0.32 & \\
\hline
\end{tabular}

* significant at $10 \% ; * *$ significant at $5 \% ; * *$ significant at $1 \%$ 
Table 2.2: Roles of Parents' Education by Cohort (Female, above 25)

\begin{tabular}{|c|c|c|c|c|c|c|c|c|c|c|c|c|c|c|}
\hline \multirow{3}{*}{$\begin{array}{l}\text { Birth Cohort } \\
\text { PAEDUC }\end{array}$} & \multirow{2}{*}{\multicolumn{2}{|c|}{$1935-39$}} & \multirow{2}{*}{\multicolumn{2}{|c|}{$1940-44$}} & \multicolumn{6}{|c|}{ Dependent varlable is EDUC } & \multirow{2}{*}{\multicolumn{2}{|c|}{$1960-64$}} & \multirow{2}{*}{\multicolumn{2}{|c|}{$1965-69$}} \\
\hline & & & & & $1945-49$ & & $1950-54$ & & $1955-59$ & & & & & \\
\hline & $\begin{array}{l}0.125 \\
0.024\end{array}$ & $* * *$ & $\begin{array}{l}0.171 \\
0.021\end{array}$ & $* *$ & $\begin{array}{l}0.158 \\
0.018\end{array}$ & $* * *$ & $\begin{array}{l}0.172 \\
0.020\end{array}$ & $* *$ & $\begin{array}{l}0.192 \\
0.019\end{array}$ & $* * *$ & $\begin{array}{l}0.211 \\
0.023\end{array}$ & $* * *$ & $\begin{array}{l}0.200 \\
0.035\end{array}$ & $* *$ \\
\hline MAEDUC & $\begin{array}{l}0.215 \\
0.028\end{array}$ & $* *$ & $\begin{array}{l}0.171 \\
0.026\end{array}$ & $* *$ & $\begin{array}{l}0.195 \\
0.022\end{array}$ & $* * *$ & $\begin{array}{l}0.145 \\
0.024\end{array}$ & $* *$ & $\begin{array}{l}0.182 \\
0.025\end{array}$ & $* *$ & $\begin{array}{l}0.210 \\
0.030\end{array}$ & $* * *$ & $\begin{array}{l}0.222 \\
0.044\end{array}$ & $* *$ \\
\hline AGE & $\begin{array}{l}0.038 \\
0.009\end{array}$ & $* * *$ & $\begin{array}{l}0.042 \\
0.008\end{array}$ & $* *$ & $\begin{array}{l}0.050 \\
0.007\end{array}$ & $* *$ & $\begin{array}{l}0.053 \\
0.009\end{array}$ & $* *$ & $\begin{array}{l}0.053 \\
0.012\end{array}$ & $* *$ & $\begin{array}{l}0.025 \\
0.020\end{array}$ & & $\begin{array}{l}0.028 \\
0.046\end{array}$ & \\
\hline SIBS & $\begin{array}{l}-0.152 \\
0.025\end{array}$ & $* * *$ & $\begin{array}{c}-0.138 \\
0.025\end{array}$ & $* *$ & $\begin{array}{c}-0.103 \\
0.021\end{array}$ & $* * *$ & $\begin{array}{l}-0.139 \\
0.023\end{array}$ & $* *$ & $\begin{array}{c}-0.079 \\
0.023\end{array}$ & $* * *$ & $\begin{array}{l}-0.085 \\
0.030\end{array}$ & $* * *$ & $\begin{array}{l}-0.019 \\
0.050\end{array}$ & \\
\hline BLACK & $\begin{array}{l}0.254 \\
0.273\end{array}$ & & $\begin{array}{l}0.389 \\
0.235\end{array}$ & * & $\begin{array}{l}0.496 \\
0.189\end{array}$ & $* *$ & $\begin{array}{l}0.530 \\
0.196\end{array}$ & $* *$ & $\begin{array}{l}0.469 \\
0.209\end{array}$ & $*$ & $\begin{array}{l}0.103 \\
0.249\end{array}$ & & $\begin{array}{l}0.158 \\
0.367\end{array}$ & \\
\hline PROTESTANT & $\begin{array}{l}0.138 \\
0.290\end{array}$ & & $\begin{array}{l}-0.201 \\
0.246\end{array}$ & & $\begin{array}{c}-0.510 \\
0.231\end{array}$ & $*$ & $\begin{array}{l}-0.386 \\
0.278\end{array}$ & & $\begin{array}{c}-0.259 \\
0.306\end{array}$ & & $\begin{array}{l}-0.189 \\
0.289\end{array}$ & & $\begin{array}{c}-0.368 \\
0.355\end{array}$ & \\
\hline CATHOLIC & $\begin{array}{l}0.172 \\
0.309\end{array}$ & & $\begin{array}{l}-0.024 \\
0.263\end{array}$ & & $\begin{array}{c}-0.060 \\
0.236\end{array}$ & & $\begin{array}{l}-0.050 \\
0.284\end{array}$ & & $\begin{array}{c}-0.035 \\
0.313\end{array}$ & & $\begin{array}{l}0.105 \\
0.296\end{array}$ & & $\begin{array}{l}0.378 \\
0.370\end{array}$ & \\
\hline JEWISH & $\begin{array}{l}1.523 \\
0.637\end{array}$ & $* *$ & $\begin{array}{l}0.695 \\
0.511\end{array}$ & & $\begin{array}{l}1.213 \\
0.431\end{array}$ & $* *$ & $\begin{array}{l}0.650 \\
0.469\end{array}$ & & $\begin{array}{l}1.342 \\
0.476\end{array}$ & $* *$ & $\begin{array}{l}0.140 \\
0.683\end{array}$ & & $\begin{array}{l}0.295 \\
0.813\end{array}$ & \\
\hline FARM & $\begin{array}{c}-0.324 \\
0.267\end{array}$ & & $\begin{array}{l}0.132 \\
0.258\end{array}$ & & $\begin{array}{c}-0.176 \\
0.224\end{array}$ & & $\begin{array}{l}0.678 \\
0.254\end{array}$ & $\cdots$ & $\begin{array}{l}0.291 \\
0.264\end{array}$ & & $\begin{array}{l}0.983 \\
0.315\end{array}$ & $* *$ & $\begin{array}{l}0.585 \\
0.483\end{array}$ & \\
\hline SMALL TOWN & $\begin{array}{l}0.020 \\
0.242\end{array}$ & & $\begin{array}{l}-0.101 \\
0.228\end{array}$ & & $\begin{array}{l}0.170 \\
0.186\end{array}$ & & $\begin{array}{l}0.159 \\
0.211\end{array}$ & & $\begin{array}{c}-0.252 \\
0.202\end{array}$ & & $\begin{array}{l}0.532 \\
0.237\end{array}$ & $*$ & $\begin{array}{l}-0.490 \\
0.356\end{array}$ & \\
\hline MID CITY & $\begin{array}{l}0.095 \\
0.292\end{array}$ & & $\begin{array}{l}0.027 \\
0.261\end{array}$ & & $\begin{array}{l}0.175 \\
0.212\end{array}$ & & $\begin{array}{l}0.402 \\
0.234\end{array}$ & * & $\begin{array}{c}-0.099 \\
0.222\end{array}$ & & $\begin{array}{l}0.738 \\
0.263\end{array}$ & $* * *$ & $\begin{array}{c}-0.554 \\
0.397\end{array}$ & \\
\hline SUB CITY & $\begin{array}{l}-0.034 \\
0.326\end{array}$ & & $\begin{array}{l}0.131 \\
0.285\end{array}$ & & $\begin{array}{l}0.457 \\
0.223\end{array}$ & $*$ & $\begin{array}{l}0.620 \\
0.246\end{array}$ & $*$ & $\begin{array}{c}-0.159 \\
0.227\end{array}$ & & $\begin{array}{l}0.733 \\
0.275\end{array}$ & $* * *$ & $\begin{array}{l}0.330 \\
0.410\end{array}$ & \\
\hline LARGE CITY & $\begin{array}{l}0.202 \\
0.289\end{array}$ & & $\begin{array}{c}-0.016 \\
0.273\end{array}$ & & $\begin{array}{l}0.180 \\
0.218\end{array}$ & & $\begin{array}{l}0.301 \\
0.241\end{array}$ & & $\begin{array}{c}-0.361 \\
0.243\end{array}$ & & $\begin{array}{l}0.700 \\
0.282\end{array}$ & $*$ & $\begin{array}{c}-0.483 \\
0.427\end{array}$ & \\
\hline NEW ENGLAND & $\begin{array}{l}0.199 \\
0.425\end{array}$ & & $\begin{array}{l}0.484 \\
0.435\end{array}$ & & $\begin{array}{c}-0.983 \\
0.353\end{array}$ & $* *$ & $\begin{array}{l}-0.911 \\
0.388\end{array}$ & $*$ & $\begin{array}{c}-0.189 \\
0.393\end{array}$ & & $\begin{array}{c}-1.031 \\
0.470\end{array}$ & $*$ & $\begin{array}{l}-0.250 \\
0.640\end{array}$ & \\
\hline MID. ATLANTIC & $\begin{array}{l}0.122 \\
0.353\end{array}$ & & $\begin{array}{c}-0.079 \\
0.345\end{array}$ & & $\begin{array}{c}-0.710 \\
0.286\end{array}$ & $*$ & $\begin{array}{c}-0.459 \\
0.306\end{array}$ & & $\begin{array}{c}-0.284 \\
0.332\end{array}$ & & $\begin{array}{c}-1.331 \\
0.367\end{array}$ & $* * *$ & $\begin{array}{c}-0.171 \\
0.552\end{array}$ & \\
\hline E.N. CENTRAL & $\begin{array}{l}-0.015 \\
0.348\end{array}$ & & $\begin{array}{l}-0.215 \\
0.338\end{array}$ & & $\begin{array}{c}-0.659 \\
0.285\end{array}$ & $*$ & $\begin{array}{l}-0.577 \\
0.297\end{array}$ & • & $\begin{array}{c}-0.445 \\
0.322\end{array}$ & & $\begin{array}{c}-0.961 \\
0.356\end{array}$ & $* * *$ & $\begin{array}{c}-0.354 \\
0.503\end{array}$ & \\
\hline W.N. CENTRAL & $\begin{array}{l}0.319 \\
0.390\end{array}$ & & $\begin{array}{l}-0.011 \\
0.378\end{array}$ & & $\begin{array}{l}-0.426 \\
0.326\end{array}$ & & $\begin{array}{l}-0.594 \\
0.338\end{array}$ & * & $\begin{array}{c}-0.215 \\
0.366\end{array}$ & & $\begin{array}{c}-0.746 \\
0.421\end{array}$ & * & $\begin{array}{l}0.230 \\
0.558\end{array}$ & \\
\hline S. ATL_ANTIC & $\begin{array}{l}0.181 \\
0.371\end{array}$ & & $\begin{array}{l}0.032 \\
0.359\end{array}$ & & $\begin{array}{l}-0.800 \\
0.300\end{array}$ & $* *$ & $\begin{array}{l}-0.906 \\
0.312\end{array}$ & $* *$ & $\begin{array}{l}-0.541 \\
0.340\end{array}$ & & $\begin{array}{l}-0.714 \\
0.384\end{array}$ & * & $\begin{array}{l}-0.250 \\
0.542\end{array}$ & \\
\hline E.S. CENTRAL & $\begin{array}{l}0.456 \\
0.421\end{array}$ & & $\begin{array}{l}0.040 \\
0.404\end{array}$ & & $\begin{array}{c}-0.506 \\
0.332\end{array}$ & & $\begin{array}{l}-0.501 \\
0.355\end{array}$ & & $\begin{array}{c}-0.150 \\
0.387\end{array}$ & & $\begin{array}{c}-0.748 \\
0.459\end{array}$ & & $\begin{array}{c}-0.109 \\
0.626\end{array}$ & \\
\hline W.S. CENTRAL & $\begin{array}{l}0.435 \\
0.401\end{array}$ & & $\begin{array}{l}-0.210 \\
0.376\end{array}$ & & $\begin{array}{c}-0.558 \\
0.316\end{array}$ & * & $\begin{array}{l}-0.510 \\
0.335\end{array}$ & & $\begin{array}{c}-0.298 \\
0.364\end{array}$ & & $\begin{array}{c}-1.030 \\
0.412\end{array}$ & $*$ & $\begin{array}{l}-0.046 \\
0.570\end{array}$ & \\
\hline MOUNTAIN & $\begin{array}{l}0.549 \\
0.474\end{array}$ & & $\begin{array}{l}-0.175 \\
0.453\end{array}$ & & $\begin{array}{r}-0.327 \\
0.376\end{array}$ & & $\begin{array}{l}-0.934 \\
0.390\end{array}$ & $*$ & $\begin{array}{c}-0.064 \\
0.387\end{array}$ & & $\begin{array}{c}-1.158 \\
0.448\end{array}$ & $* * *$ & $\begin{array}{l}-0.430 \\
0.594\end{array}$ & \\
\hline PACIFIC & $\begin{array}{l}0.415 \\
0.417\end{array}$ & & $\begin{array}{l}0.043 \\
0.372\end{array}$ & & $\begin{array}{c}-0.672 \\
0.305\end{array}$ & $*$ & $\begin{array}{l}-0.764 \\
0.318\end{array}$ & $*$ & $\begin{array}{c}-0.327 \\
0.340\end{array}$ & & $\begin{array}{c}-1.423 \\
0.376\end{array}$ & $* * *$ & $\begin{array}{l}0.005 \\
0.529\end{array}$ & \\
\hline Constant & $\begin{array}{l}7.853 \\
0.632\end{array}$ & $* *$ & $\begin{array}{l}8.561 \\
0.569\end{array}$ & $* *$ & $\begin{array}{l}8.995 \\
0.476\end{array}$ & $* * *$ & $\begin{array}{l}9.306 \\
0.578\end{array}$ & $* *$ & $\begin{array}{l}8.539 \\
0.642\end{array}$ & $* *$ & $\begin{array}{l}8.726 \\
0.787\end{array}$ & $* * *$ & $\begin{array}{l}8.402 \\
1.620\end{array}$ & $* *$ \\
\hline Observations & 957 & & 1283 & & 1588 & & 1420 & & 1311 & & 812 & & 411 & \\
\hline R-squared & 0.29 & & 0.27 & & 0.31 & & 0.26 & & 0.28 & & 0.32 & & 0.32 & \\
\hline
\end{tabular}

* significant at $10 \% ; * *$ significant at $5 \% ; * * *$ significant at $1 \%$ 
Table 3.1: Women's Labor Force Participation (Goldin, 1990)

\begin{tabular}{lccccccc}
\hline Year & 1920 & 1930 & 1940 & 1950 & 1960 & 1970 & 1980 \\
LFP rate & 7.7 & 11.5 & 16.7 & 21 & 26.7 & 36.2 & 56 \\
\hline \hline
\end{tabular}

Table 3.2: Women's Labor Force Participation (McGrattan and Rogerson, 1998)

\begin{tabular}{lcccccc}
\hline Year & 1950 & 1960 & 1970 & 1980 & 1990 & Percentage Change 1950-90 \\
Females & 8.09 & 9.1 & 12.21 & 18.77 & 23.9 & 195.4 \\
Females with Child under 6 & 4.6 & 5.75 & 8.33 & 13.47 & 19.48 & 323.5 \\
Men & 41.14 & 40.67 & 40.3 & 38.7 & 40.25 & -2.2 \\
\hline \hline
\end{tabular}


Table 4.1: Effects of Maternal Employment

\begin{tabular}{|c|c|c|c|c|}
\hline \multirow{2}{*}{$\begin{array}{l}\text { Variables } \\
\text { MAWKBORN }\end{array}$} & \multicolumn{3}{|c|}{$\begin{array}{c}\text { Dependent variable is EDUC } \\
\text { std.dev. }\end{array}$} & \multirow[b]{2}{*}{$\begin{array}{l}0.033 \\
0.187\end{array}$} \\
\hline & $\begin{array}{l}0.723 \\
0.714\end{array}$ & & BLACK & \\
\hline$\left(\right.$ FEMALE) ${ }^{*}$ (MAWKBORN) & $\begin{array}{l}0.294 \\
0.925\end{array}$ & & PROTESTANT & $\begin{array}{l}-0.555 \\
0.214\end{array}$ \\
\hline PAEDUC & $\begin{array}{l}0.211 \\
0.037\end{array}$ & $* * *$ & CATHOLIC & $\begin{array}{l}-0.155 \\
0.221\end{array}$ \\
\hline$($ FEMALE)*(PAEDUC) & $\begin{array}{l}-0.057 \\
0.046\end{array}$ & & JEWISH & $\begin{array}{l}0.367 \\
0.406\end{array}$ \\
\hline$\left(\right.$ PAEDUC) ${ }^{*}$ (MAWKBORN) & $\begin{array}{l}0.041 \\
0.052\end{array}$ & & FARM & $\begin{array}{l}0.465 \\
0.217\end{array}$ \\
\hline$(\text { PAEDUC })^{*}(\text { MAWKBORN })^{*}($ FEMALE $)$ & $\begin{array}{r}-0.095 \\
0.067\end{array}$ & & STOWN & $\begin{array}{l}0.358 \\
0.169\end{array}$ \\
\hline MAEDUC & $\begin{array}{l}0.163 \\
0.051\end{array}$ & $* * *$ & MID CITY & $\begin{array}{l}0.242 \\
0.189\end{array}$ \\
\hline$($ FEMALE $) *$ MAEDUC) & $\begin{array}{l}0.065 \\
0.066\end{array}$ & & SUB CITY & $\begin{array}{l}0.464 \\
0.192\end{array}$ \\
\hline$($ MAEDUC $) *(M A W K B O R N)$ & $\begin{array}{r}-0.106 \\
0.069\end{array}$ & & LARGE CITY & $\begin{array}{l}0.182 \\
0.204\end{array}$ \\
\hline$($ MAEDUC $) *(\text { MAWKBORN })^{*}($ FEMALE $)$ & $\begin{array}{l}0.052 \\
0.089\end{array}$ & & NEW ENGLAND & $\begin{array}{l}-1.171 \\
0.34\end{array}$ \\
\hline AGE & $\begin{array}{l}0.03 \\
0.02\end{array}$ & & MID. ATLANTIC & $\begin{array}{l}-1.078 \\
0.294\end{array}$ \\
\hline SIBLINGS & $\begin{array}{r}-0.115 \\
0.023\end{array}$ & $*: * *$ & E.N. CENTRAL & $\begin{array}{r}-1.162 \\
0.285\end{array}$ \\
\hline CONSTANT & $\begin{array}{c}10.452 \\
1.000\end{array}$ & $* * *$ & W.N. CENTRAL & $\begin{array}{l}-0.974 \\
0.313\end{array}$ \\
\hline FEMALE & $\begin{array}{l}-0.323 \\
0.693\end{array}$ & & S. ATLANTIC & $\begin{array}{l}-0.933 \\
0.298\end{array}$ \\
\hline COHORT $1955-59$ & $\begin{array}{r}-0.253 \\
0.207\end{array}$ & & E.S. CENTRAL & $\begin{array}{r}-1.034 \\
0.348\end{array}$ \\
\hline COHORT 1960-64 & $\begin{array}{l}-0.413 \\
0.274\end{array}$ & & W.S. CENTRAL & $\begin{array}{r}-1.074 \\
0.319\end{array}$ \\
\hline COHORT $1965-69$ & $\begin{array}{c}-0.343 \\
0.37\end{array}$ & & MOUNTAIN & $\begin{array}{l}-1.224 \\
0.348\end{array}$ \\
\hline$($ COHORT 1955-59)*(FEMALE) & $\begin{array}{l}0.157 \\
0.246\end{array}$ & & PACIFIC & $\begin{array}{r}-1.109 \\
0.296\end{array}$ \\
\hline$($ COHORT 1960-64)*(FEMALE) & $\begin{array}{l}0.266 \\
0.263\end{array}$ & & & \\
\hline$($ COHORT 1965-69)*(FEMALE) & $\begin{array}{l}0.022 \\
0.392\end{array}$ & & $\begin{array}{l}\text { Observations } \\
\text { R-squared }\end{array}$ & $\begin{array}{l}1942 \\
0.24\end{array}$ \\
\hline
\end{tabular}

Standard errors in italic

* significant at $10 \%$; ** significant at $5 \%$; $* * *$ significant at $1 \%$ 
Table 4.2: Parental Gender Specialization and Maternal Employment

\begin{tabular}{cccc}
\hline \hline Null Hypothesis & Restriction on parameters & F statistic & p-value test \\
\hline & & & \\
$\mathrm{MS}(\mathrm{w}=0)=0$ & $\mathrm{~d}(\mathrm{~m})=0$ & -0.065 & 0.3219 \\
$\mathrm{MS}(\mathrm{w}=1)=0$ & $\mathrm{~d}(\mathrm{~m})+\mathrm{f}(\mathrm{m})=0$ & -0.117 & 0.0496 \\
& & & \\
$\operatorname{PS}(\mathrm{w}=0)=0$ & $\mathrm{~d}(\mathrm{p})=0$ & 0.057 & 0.214 \\
$\operatorname{PS}(\mathrm{w}=1)=0$ & $\mathrm{~d}(\mathrm{p})+\mathrm{f}(\mathrm{p})=0$ & 0.152 & 0.0017 \\
& & & \\
\hline \hline
\end{tabular}


Table 5.1: Roles of Parents' Education by Earlier Cohort (Male, above 25)

\begin{tabular}{|c|c|c|c|c|c|c|c|c|c|c|}
\hline \multirow{3}{*}{$\begin{array}{l}\text { Birth Cohort } \\
\text { PAEDUC }\end{array}$} & \multicolumn{10}{|c|}{ Deperdent varlable is EDUC } \\
\hline & \multicolumn{2}{|l|}{$1910-14$} & \multicolumn{2}{|l|}{ 1915-19 } & \multicolumn{2}{|l|}{$1920-24$} & \multicolumn{2}{|l|}{ 1925-29 } & \multicolumn{2}{|l|}{$1930-34$} \\
\hline & $\begin{array}{l}0.213 \\
0.052\end{array}$ & $* * *$ & $\begin{array}{l}0.198 \\
0.039\end{array}$ & $* *$ & $\begin{array}{l}0.186 \\
0.040\end{array}$ & $\cdots$ & $\begin{array}{l}0.207 \\
0.039\end{array}$ & $* *$ & $\begin{array}{l}0.169 \\
0.037\end{array}$ & $\cdots$ \\
\hline MAEDUC & $\begin{array}{l}0.148 \\
0.059\end{array}$ & $*$ & $\begin{array}{l}0.176 \\
0.041\end{array}$ & $* *$ & $\begin{array}{l}0.243 \\
0.048\end{array}$ & $* *$ & $\begin{array}{l}0.141 \\
0.045\end{array}$ & $* *$ & $\begin{array}{l}0.150 \\
0.045\end{array}$ & $* * *$ \\
\hline AGE & $\begin{array}{l}0.045 \\
0.029\end{array}$ & & $\begin{array}{l}0.019 \\
0.019\end{array}$ & & $\begin{array}{l}0.033 \\
0.017\end{array}$ & $\cdot$ & $\begin{array}{l}-0.009 \\
0.016\end{array}$ & & $\begin{array}{l}0.010 \\
0.015\end{array}$ & \\
\hline SIBS & $\begin{array}{l}-0.195 \\
0.057\end{array}$ & $* * *$ & $\begin{array}{l}-0.142 \\
0.047\end{array}$ & $* *$ & $\begin{array}{r}-0.167 \\
0.040\end{array}$ & $* *$ & $\begin{array}{r}-0.183 \\
0.046\end{array}$ & $\cdots *$ & $\begin{array}{l}-0.133 \\
0.042\end{array}$ & $* * *$ \\
\hline BLACK & $\begin{array}{c}-1.689 \\
0.662\end{array}$ & $*$ & $\begin{array}{r}-1.103 \\
0.476\end{array}$ & $*$ & $\begin{array}{c}-1.677 \\
0.481\end{array}$ & $* *$ & $\begin{array}{r}-1.422 \\
0.457\end{array}$ & $* *$ & $\begin{array}{r}-0.767 \\
0.443\end{array}$ & $\cdot$ \\
\hline PROTESTANT & $\begin{array}{l}0.245 \\
0.5 E 6\end{array}$ & & $\begin{array}{l}-0.635 \\
0.439\end{array}$ & & $\begin{array}{l}0.040 \\
0.436\end{array}$ & & $\begin{array}{l}0.542 \\
0.424\end{array}$ & & $\begin{array}{l}0.725 \\
0.40 I\end{array}$ & $\cdot$ \\
\hline CATHOL.IC & $\begin{array}{l}-0.449 \\
0.652\end{array}$ & & $\begin{array}{l}0.222 \\
0.506\end{array}$ & & $\begin{array}{r}-0.086 \\
0.486\end{array}$ & & $\begin{array}{l}0.128 \\
0.464\end{array}$ & & $\begin{array}{l}0.228 \\
0.444\end{array}$ & \\
\hline JEWISH & $\begin{array}{l}1.057 \\
1.057\end{array}$ & & $\begin{array}{l}1.668 \\
0.867\end{array}$ & $\cdot$ & $\begin{array}{l}1.722 \\
0.888\end{array}$ & $\cdot$ & $\begin{array}{l}2.713 \\
0.830\end{array}$ & $* * *$ & $\begin{array}{l}1.562 \\
1.124\end{array}$ & \\
\hline FARM & $\begin{array}{l}-0.532 \\
0.643\end{array}$ & & $\begin{array}{l}-0.008 \\
0.556\end{array}$ & & $\begin{array}{l}-0.709 \\
0.474\end{array}$ & & $\begin{array}{l}-0.432 \\
0.507\end{array}$ & & $\begin{array}{l}-0.076 \\
0.460\end{array}$ & \\
\hline SMALL TOWN & $\begin{array}{l}1.178 \\
0.64 I\end{array}$ & * & $\begin{array}{l}1.240 \\
0.551\end{array}$ & $*$ & $\begin{array}{l}0.274 \\
0.474\end{array}$ & & $\begin{array}{l}0.798 \\
0.503\end{array}$ & & $\begin{array}{l}1.017 \\
0.434\end{array}$ & $*$ \\
\hline MID CITY & $\begin{array}{l}1.549 \\
0.779\end{array}$ & $*$ & $\begin{array}{l}0.251 \\
0.628\end{array}$ & & $\begin{array}{l}0.235 \\
0.545\end{array}$ & & $\begin{array}{l}1.234 \\
0.573\end{array}$ & $*$ & $\begin{array}{l}1.624 \\
0.540\end{array}$ & $* * *$ \\
\hline SUB CITY & $\begin{array}{l}2.045 \\
1.392\end{array}$ & & $\begin{array}{l}2.216 \\
0.786\end{array}$ & $* *$ & $\begin{array}{l}0.839 \\
0.893\end{array}$ & & $\begin{array}{l}0.970 \\
0.696\end{array}$ & & $\begin{array}{l}1.551 \\
0.658\end{array}$ & $* *$ \\
\hline LARGE CITY & $\begin{array}{l}0.999 \\
0.744\end{array}$ & & $\begin{array}{l}1.911 \\
0.632\end{array}$ & $* * *$ & $\begin{array}{l}0.508 \\
0.562\end{array}$ & & $\begin{array}{l}1.432 \\
0.562\end{array}$ & $*$ & $\begin{array}{l}1.451 \\
0.502\end{array}$ & $* *$ \\
\hline NEW ENGL_AND & $\begin{array}{l}2.522 \\
1.163\end{array}$ & $*$ & $\begin{array}{l}0.638 \\
0.942\end{array}$ & & $\begin{array}{l}0.650 \\
0.873\end{array}$ & & $\begin{array}{l}0.315 \\
0.965\end{array}$ & & $\begin{array}{l}-0.436 \\
0.947\end{array}$ & \\
\hline MID. ATL_ANTIC & $\begin{array}{l}1.679 \\
0.919\end{array}$ & * & $\begin{array}{l}0.161 \\
0.851\end{array}$ & & $\begin{array}{l}0.945 \\
0.776\end{array}$ & & $\begin{array}{r}-0.161 \\
0.884\end{array}$ & & $\begin{array}{l}0.890 \\
0.719\end{array}$ & \\
\hline E.N. CENTRAL & $\begin{array}{l}1.515 \\
0.903\end{array}$ & $\cdot$ & $\begin{array}{l}0.667 \\
0.839\end{array}$ & & $\begin{array}{l}1.659 \\
0.766\end{array}$ & $*$ & $\begin{array}{l}-0.327 \\
0.874\end{array}$ & & $\begin{array}{l}-0.325 \\
0.704\end{array}$ & \\
\hline W.N. CENTRAL & $\begin{array}{l}2.128 \\
0.956\end{array}$ & $*$ & $\begin{array}{l}0.345 \\
0.907\end{array}$ & & $\begin{array}{l}1.346 \\
0.809\end{array}$ & $\cdot$ & $\begin{array}{l}0.331 \\
0.903\end{array}$ & & $\begin{array}{l}-0.576 \\
0.774\end{array}$ & \\
\hline S. ATLANTIC & $\begin{array}{l}0.710 \\
0.936\end{array}$ & & $\begin{array}{l}0.504 \\
0.874\end{array}$ & & $\begin{array}{l}0.510 \\
0.796\end{array}$ & & $\begin{array}{r}-0.199 \\
0.906\end{array}$ & & $\begin{array}{c}-0.358 \\
0.743\end{array}$ & \\
\hline E.S. CENTRAL & $\begin{array}{l}1.581 \\
1.052\end{array}$ & & $\begin{array}{l}-0.456 \\
0.933\end{array}$ & & $\begin{array}{r}-0.017 \\
0.849\end{array}$ & & $\begin{array}{l}-0.448 \\
0.996\end{array}$ & & $\begin{array}{l}-0.504 \\
0.820\end{array}$ & \\
\hline W.S. CENTRAL & $\begin{array}{l}1.768 \\
1.015\end{array}$ & $*$ & $\begin{array}{l}-0.210 \\
0.916\end{array}$ & & $\begin{array}{l}0.358 \\
0.837\end{array}$ & & $\begin{array}{l}-0.155 \\
0.941\end{array}$ & & $\begin{array}{l}0.166 \\
0.767\end{array}$ & \\
\hline MOUNTAIN & $\begin{array}{l}2.635 \\
1.323\end{array}$ & $*$ & $\begin{array}{l}-0.208 \\
0.991\end{array}$ & & $\begin{array}{l}1.372 \\
0.992\end{array}$ & & $\begin{array}{l}0.617 \\
1.075\end{array}$ & & $\begin{array}{c}-0.142 \\
0.913\end{array}$ & \\
\hline PACIFIC & $\begin{array}{l}1.512 \\
1.158\end{array}$ & & $\begin{array}{l}0.222 \\
1.009\end{array}$ & & $\begin{array}{l}0.538 \\
0.901\end{array}$ & & $\begin{array}{l}0.433 \\
0.956\end{array}$ & & $\begin{array}{l}0.191 \\
0.765\end{array}$ & \\
\hline Constant & $\begin{array}{l}4.265 \\
2.167\end{array}$ & $*$ & $\begin{array}{l}7.633 \\
1.573\end{array}$ & $* *$ & $\begin{array}{l}6.661 \\
1.316\end{array}$ & $* *$ & $\begin{array}{l}9.941 \\
1.340\end{array}$ & $* *$ & $\begin{array}{l}8.928 \\
1.161\end{array}$ & $\cdots *$ \\
\hline Observations & 350 & & 535 & & 632 & & 677 & & 664 & \\
\hline R-squared & 0.4 & & 0.36 & & 0.38 & & 0.3 & & 0.26 & \\
\hline
\end{tabular}

* significant at $10 \% ; * *$ significant at $5 \% ; * * *$ significant at $1 \%$ 
Table 5.2: Roles of Parents' Education by Earlier Cohort (Female, above 25)

\begin{tabular}{|c|c|c|c|c|c|c|c|c|c|c|}
\hline \multirow{3}{*}{$\begin{array}{l}\text { Barth Cohort } \\
\text { PAEDUC }\end{array}$} & \multicolumn{10}{|c|}{ Dependent varlable is EDUC } \\
\hline & \multicolumn{2}{|l|}{$1910-14$} & \multicolumn{2}{|c|}{$1915-19$} & \multicolumn{2}{|c|}{$1920-24$} & \multicolumn{2}{|l|}{$1925-29$} & \multicolumn{2}{|l|}{$1930-34$} \\
\hline & $\begin{array}{l}0.138 \\
0.044\end{array}$ & $\cdots$ & $\begin{array}{l}0.156 \\
0.030\end{array}$ & $* * *$ & $\begin{array}{l}0.124 \\
0.026\end{array}$ & $* *$ & $\begin{array}{l}0.186 \\
0.029\end{array}$ & $* *$ & $\begin{array}{l}0.160 \\
0.026\end{array}$ & $* *$ \\
\hline MAEDUC & $\begin{array}{l}0.241 \\
0.043\end{array}$ & $* *$ & $\begin{array}{l}0.227 \\
0.034\end{array}$ & $* * *$ & $\begin{array}{l}0.212 \\
0.028\end{array}$ & $* * *$ & $\begin{array}{l}0.127 \\
0.031\end{array}$ & $* *$ & $\begin{array}{l}0.258 \\
0.031\end{array}$ & $* *$ \\
\hline AGE & $\begin{array}{l}0.000 \\
0.020\end{array}$ & & $\begin{array}{c}-0.004 \\
0.013\end{array}$ & & $\begin{array}{l}0.006 \\
0.011\end{array}$ & & $\begin{array}{l}0.023 \\
0.011\end{array}$ & $*$ & $\begin{array}{l}0.011 \\
0.010\end{array}$ & \\
\hline SIBS & $\begin{array}{c}-0.143 \\
0.041\end{array}$ & $* *$ & $\begin{array}{l}-0.192 \\
0.033\end{array}$ & $* * *$ & $\begin{array}{r}-0.147 \\
0.027\end{array}$ & $\cdots$ & $\begin{array}{l}-0.154 \\
0.031\end{array}$ & $* *$ & $\begin{array}{l}-0.116 \\
0.029\end{array}$ & $\cdots$ \\
\hline BLACK & $\begin{array}{c}-0.162 \\
0.451\end{array}$ & & $\begin{array}{l}0.078 \\
0.374\end{array}$ & & $\begin{array}{r}-0.637 \\
0.303\end{array}$ & $*$ & $\begin{array}{l}-0.458 \\
0.324\end{array}$ & & $\begin{array}{l}0.706 \\
0.286\end{array}$ & $* *$ \\
\hline PROTESTANT & $\begin{array}{l}0.168 \\
0.414\end{array}$ & & $\begin{array}{l}0.387 \\
0.358\end{array}$ & & $\begin{array}{c}-0.268 \\
0.319\end{array}$ & & $\begin{array}{l}-0.218 \\
0.303\end{array}$ & & $\begin{array}{l}0.200 \\
0.299\end{array}$ & \\
\hline CATHOLIC & $\begin{array}{c}-0.567 \\
0.490\end{array}$ & & $\begin{array}{l}0.140 \\
0.388\end{array}$ & & $\begin{array}{c}-0.287 \\
0.342\end{array}$ & & $\begin{array}{l}0.047 \\
0.340\end{array}$ & & $\begin{array}{l}0.270 \\
0.324\end{array}$ & \\
\hline JEWISH & $\begin{array}{l}2.962 \\
0.976\end{array}$ & $* *$ & $\begin{array}{l}2.264 \\
0.736\end{array}$ & $* * *$ & $\begin{array}{r}-0.391 \\
0.664\end{array}$ & & $\begin{array}{l}1.015 \\
0.662\end{array}$ & & $\begin{array}{l}1.713 \\
0.604\end{array}$ & $* *$ \\
\hline FARM & $\begin{array}{l}0.036 \\
0.469\end{array}$ & & $\begin{array}{c}-0.232 \\
0.384\end{array}$ & & $\begin{array}{l}0.015 \\
0.334\end{array}$ & & $\begin{array}{c}-0.029 \\
0.326\end{array}$ & & $\begin{array}{l}0.091 \\
0.306\end{array}$ & \\
\hline SMALL TOWN & $\begin{array}{l}1.342 \\
0.472\end{array}$ & $* *$ & $\begin{array}{l}0.421 \\
0.386\end{array}$ & & $\begin{array}{l}0.323 \\
0.324\end{array}$ & & $\begin{array}{l}0.496 \\
0.309\end{array}$ & & $\begin{array}{l}0.401 \\
0.296\end{array}$ & \\
\hline MID CITY & $\begin{array}{l}1.070 \\
0.566\end{array}$ & $\cdot$ & $\begin{array}{l}0.620 \\
0.442\end{array}$ & & $\begin{array}{l}0.333 \\
0.374\end{array}$ & & $\begin{array}{l}0.546 \\
0.353\end{array}$ & & $\begin{array}{l}0.744 \\
0.352\end{array}$ & $* *$ \\
\hline SUB CITY & $\begin{array}{l}1.729 \\
0.722\end{array}$ & $*$ & $\begin{array}{l}0.779 \\
0.558\end{array}$ & & $\begin{array}{l}0.753 \\
0.458\end{array}$ & & $\begin{array}{l}0.905 \\
0.430\end{array}$ & $*$ & $\begin{array}{l}0.715 \\
0.400\end{array}$ & $*$ \\
\hline LARGE CITY & $\begin{array}{l}0.406 \\
0.561\end{array}$ & & $\begin{array}{l}0.003 \\
0.443\end{array}$ & & $\begin{array}{l}0.342 \\
0.363\end{array}$ & & $\begin{array}{l}0.381 \\
0.358\end{array}$ & & $\begin{array}{l}0.657 \\
0.341\end{array}$ & * \\
\hline NEW ENGL_AND & $\begin{array}{l}0.043 \\
0.890\end{array}$ & & $\begin{array}{l}0.069 \\
0.641\end{array}$ & & $\begin{array}{l}1.498 \\
0.546\end{array}$ & $* *$ & $\begin{array}{l}1.608 \\
0.522\end{array}$ & $* *$ & $\begin{array}{l}1.470 \\
0.546\end{array}$ & $* * *$ \\
\hline MID. ATLANTIC & $\begin{array}{l}0.036 \\
0.791\end{array}$ & & $\begin{array}{l}0.699 \\
0.530\end{array}$ & & $\begin{array}{l}1.671 \\
0.485\end{array}$ & $* *$ & $\begin{array}{l}1.308 \\
0.465\end{array}$ & $* *$ & $\begin{array}{l}0.975 \\
0.407\end{array}$ & $* *$ \\
\hline EN. CENTRAL & $\begin{array}{c}-0.052 \\
0.766\end{array}$ & & $\begin{array}{l}0.708 \\
0.529\end{array}$ & & $\begin{array}{l}1.439 \\
0.480\end{array}$ & $* * *$ & $\begin{array}{l}1.637 \\
0.452\end{array}$ & $* *$ & $\begin{array}{l}1.055 \\
0.396\end{array}$ & $* * *$ \\
\hline W.N. CENTRAL & $\begin{array}{l}0.418 \\
0.804\end{array}$ & & $\begin{array}{l}1.067 \\
0.545\end{array}$ & $\cdot$ & $\begin{array}{l}1.715 \\
0.513\end{array}$ & $* *$ & $\begin{array}{l}1.781 \\
0.500\end{array}$ & $* *$ & $\begin{array}{l}1.481 \\
0.439\end{array}$ & $* *$ \\
\hline S. ATLANTIC & $\begin{array}{l}-0.352 \\
0.824\end{array}$ & & $\begin{array}{l}0.276 \\
0.536\end{array}$ & & $\begin{array}{l}0.925 \\
0.499\end{array}$ & * & $\begin{array}{l}1.384 \\
0.483\end{array}$ & $\cdots *$ & $\begin{array}{l}1.016 \\
0.420\end{array}$ & $* *$ \\
\hline E.S. CENTRAL & $\begin{array}{c}-0.398 \\
0.828\end{array}$ & & $\begin{array}{c}-0.023 \\
0.606\end{array}$ & & $\begin{array}{l}0.977 \\
0.534\end{array}$ & * & $\begin{array}{l}1.121 \\
0.523\end{array}$ & $*$ & $\begin{array}{l}0.933 \\
0.469\end{array}$ & $* *$ \\
\hline W.S. CENTRAL & $\begin{array}{c}-0.288 \\
0.867\end{array}$ & & $\begin{array}{l}1.111 \\
0.589\end{array}$ & * & $\begin{array}{l}0.927 \\
0.534\end{array}$ & * & $\begin{array}{l}1.449 \\
0.523\end{array}$ & $* *$ & $\begin{array}{l}0.843 \\
0.442\end{array}$ & * \\
\hline MOUNTAIN & $\begin{array}{l}0.376 \\
0.921\end{array}$ & & $\begin{array}{l}1.489 \\
0.667\end{array}$ & $*$ & $\begin{array}{l}2.002 \\
0.618\end{array}$ & $* * *$ & $\begin{array}{l}1.978 \\
0.562\end{array}$ & $* *$ & $\begin{array}{l}1.179 \\
0.508\end{array}$ & $* *$ \\
\hline PACIFIC & $\begin{array}{l}0.518 \\
0.960\end{array}$ & & $\begin{array}{l}1.460 \\
0.657\end{array}$ & $*$ & $\begin{array}{l}1.224 \\
0.561\end{array}$ & $*$ & $\begin{array}{l}1.489 \\
0.525\end{array}$ & $\cdots$ & $\begin{array}{l}1.176 \\
0.478\end{array}$ & $* *$ \\
\hline Constant & $\begin{array}{l}8.132 \\
1.605\end{array}$ & $* *$ & $\begin{array}{l}8.430 \\
1.070\end{array}$ & $* *$ & $\begin{array}{l}8.057 \\
0.851\end{array}$ & $* *$ & $\begin{array}{l}7.229 \\
0.824\end{array}$ & $* *$ & $\begin{array}{l}6.881 \\
0.762\end{array}$ & $* *$ \\
\hline Observations & 478 & & 670 & & 838 & & 810 & & 823 & \\
\hline R-squared & 0.38 & & 0.38 & & 0.34 & & 0.31 & & 0.37 & \\
\hline
\end{tabular}

* significant at $10 \% ; * *$ significant at $5 \% ; * * *$ significant at $1 \%$ 
Table 6.1: Summary Characteristics by Cohort (Male, above 30)

\begin{tabular}{|c|c|c|c|c|c|c|c|}
\hline$\overline{\overline{\text { Variable }}}$ & & & & $\begin{array}{l}\text { mple Mear } \\
\text { Std. Dev. }\end{array}$ & & & \\
\hline Birth Cohort & $1935-39$ & $1940-44$ & $1945-49$ & $1950-54$ & $1955-59$ & $1960-64$ & $1965-69$ \\
\hline No. observations & 814 & 1011 & 1080 & 937 & 721 & 432 & 116 \\
\hline AGE & $\begin{array}{l}46.40 \\
8.20\end{array}$ & $\begin{array}{c}42.40 \\
7.87\end{array}$ & $\begin{array}{l}40.83 \\
6.29\end{array}$ & $\begin{array}{c}37.93 \\
5.03\end{array}$ & $\begin{array}{c}35.86 \\
3.75\end{array}$ & $\begin{array}{c}33.40 \\
2.25\end{array}$ & $\begin{array}{c}31.34 \\
1.13\end{array}$ \\
\hline EDUC & $\begin{array}{c}13.32 \\
3.20\end{array}$ & $\begin{array}{c}13.80 \\
3.14\end{array}$ & $\begin{array}{l}14.27 \\
2.98\end{array}$ & $\begin{array}{c}14.26 \\
2.77\end{array}$ & $\begin{array}{c}14.10 \\
2.74\end{array}$ & $\begin{array}{l}14.07 \\
2.54\end{array}$ & $\begin{array}{c}14.10 \\
2.70\end{array}$ \\
\hline PAEDUC & $\begin{array}{l}9.31 \\
4.14\end{array}$ & $\begin{array}{l}10.15 \\
4.03\end{array}$ & $\begin{array}{c}10.70 \\
3.92\end{array}$ & $\begin{array}{c}11.53 \\
3.90\end{array}$ & $\begin{array}{c}12.04 \\
3.95\end{array}$ & $\begin{array}{c}12.44 \\
3.59\end{array}$ & $\begin{array}{c}12.79 \\
3.68\end{array}$ \\
\hline MAEDUC & $\begin{array}{c}10.06 \\
3.46\end{array}$ & $\begin{array}{c}10.75 \\
3.40\end{array}$ & $\begin{array}{l}10.98 \\
3.04\end{array}$ & $\begin{array}{c}11.56 \\
3.20\end{array}$ & $\begin{array}{c}12.03 \\
3.17\end{array}$ & $\begin{array}{l}12.26 \\
2.65\end{array}$ & $\begin{array}{l}12.60 \\
2.58\end{array}$ \\
\hline SIBS & $\begin{array}{l}3.55 \\
3.07\end{array}$ & $\begin{array}{l}3.31 \\
2.73\end{array}$ & $\begin{array}{l}3.38 \\
2.69\end{array}$ & $\begin{array}{l}3.42 \\
2.63\end{array}$ & $\begin{array}{l}3.49 \\
2.42\end{array}$ & $\begin{array}{l}3.23 \\
2.19\end{array}$ & $\begin{array}{l}3.49 \\
2.54\end{array}$ \\
\hline BLACK & 0.091 & 0.085 & 0.071 & 0.079 & 0.083 & 0.079 & 0.052 \\
\hline PROTESTANT & 0.628 & 0.631 & 0.609 & 0.580 & 0.527 & 0.530 & 0.466 \\
\hline CATHOLIC & 0.248 & 0.251 & 0.311 & 0.323 & 0.356 & 0.350 & 0.379 \\
\hline JEWISH & 0.020 & 0.031 & 0.025 & 0.026 & 0.028 & 0.007 & 0.009 \\
\hline COUNTRY & 0.128 & 0.102 & 0.097 & 0.111 & 0.119 & 0.134 & 0.103 \\
\hline FARM & 0.208 & 0.189 & 0.144 & 0.107 & 0.118 & 0.083 & 0.078 \\
\hline SMALL TOWN & 0.312 & 0.314 & 0.339 & 0.299 & 0.297 & 0.287 & 0.276 \\
\hline MID CITY & 0.117 & 0.136 & 0.158 & 0.173 & 0.151 & 0.153 & 0.207 \\
\hline SUB CITY & 0.080 & 0.119 & 0.128 & 0.154 & 0.183 & 0.197 & 0.181 \\
\hline LARGE CITY & 0.156 & 0.140 & 0.134 & 0.157 & 0.132 & 0.146 & 0.155 \\
\hline NEW ENGLAND & 0.048 & 0.042 & 0.048 & 0.046 & 0.057 & 0.069 & 0.078 \\
\hline MID. ATLANTIC & 0.167 & 0.162 & 0.175 & 0.160 & 0.169 & 0.144 & 0.095 \\
\hline E.N. CENTRAL & 0.177 & 0.219 & 0.224 & 0.225 & 0.219 & 0.220 & 0.198 \\
\hline W.N. CENTRAL & 0.115 & 0.077 & 0.076 & 0.090 & 0.079 & 0.060 & 0.086 \\
\hline S. ATLANTIC & 0.149 & 0.152 & 0.142 & 0.127 & 0.126 & 0.139 & 0.129 \\
\hline E.S. CENTRAL & 0.076 & 0.078 & 0.045 & 0.058 & 0.053 & 0.046 & 0.034 \\
\hline W.S. CENTRAL & 0.090 & 0.081 & 0.085 & 0.073 & 0.067 & 0.067 & 0.112 \\
\hline MOUNTAIN & 0.036 & 0.039 & 0.053 & 0.051 & 0.044 & 0.053 & 0.052 \\
\hline PACIFIC & 0.098 & 0.099 & 0.100 & 0.108 & 0.115 & 0.130 & 0.112 \\
\hline FOREIGN & 0.001 & 0.001 & 0.002 & 0.010 & 0.010 & 0.016 & 0.069 \\
\hline
\end{tabular}


Table 6.2: Summary Characteristics by Cohort (Female, above 30)

\begin{tabular}{|c|c|c|c|c|c|c|c|}
\hline \multirow{2}{*}{$\begin{array}{l}\text { Variable } \\
\text { Birth Cohort }\end{array}$} & \multicolumn{7}{|c|}{$\begin{array}{c}\text { Sample Means } \\
\text { Std. Dev. }\end{array}$} \\
\hline & $1935-39$ & $1940-44$ & $1945-49$ & $1950-54$ & $1955-59$ & $1960-64$ & $1965-69$ \\
\hline No. observations & 957 & 1239 & 1248 & 1146 & 899 & 479 & 132 \\
\hline AGE & $\begin{array}{l}46.60 \\
8.18\end{array}$ & $\begin{array}{c}42.86 \\
7.97\end{array}$ & $\begin{array}{l}40.72 \\
6.40\end{array}$ & $\begin{array}{c}37.79 \\
5.00\end{array}$ & $\begin{array}{c}35.65 \\
3.71\end{array}$ & $\begin{array}{l}33.35 \\
2.31\end{array}$ & $\begin{array}{c}31.25 \\
1.11\end{array}$ \\
\hline EDUC & $\begin{array}{l}12.72 \\
2.60\end{array}$ & $\begin{array}{l}13.24 \\
2.70\end{array}$ & $\begin{array}{l}13.73 \\
2.58\end{array}$ & $\begin{array}{l}13.85 \\
2.57\end{array}$ & $\begin{array}{l}14.05 \\
2.53\end{array}$ & $\begin{array}{l}13.98 \\
2.36\end{array}$ & $\begin{array}{l}14.02 \\
2.56\end{array}$ \\
\hline PAEDUC & $\begin{array}{l}9.31 \\
3.86\end{array}$ & $\begin{array}{c}10.07 \\
4.08\end{array}$ & $\begin{array}{c}10.61 \\
3.89\end{array}$ & $\begin{array}{c}10.93 \\
3.93\end{array}$ & $\begin{array}{c}11.89 \\
4.02\end{array}$ & $\begin{array}{c}12.26 \\
3.74\end{array}$ & $\begin{array}{c}12.29 \\
3.89\end{array}$ \\
\hline MAEDUC & $\begin{array}{l}9.89 \\
3.28\end{array}$ & $\begin{array}{c}10.46 \\
3.30\end{array}$ & $\begin{array}{c}11.03 \\
3.25\end{array}$ & $\begin{array}{c}11.23 \\
3.14\end{array}$ & $\begin{array}{c}11.77 \\
3.08\end{array}$ & $\begin{array}{l}12.39 \\
2.72\end{array}$ & $\begin{array}{c}12.42 \\
3.46\end{array}$ \\
\hline SIBS & $\begin{array}{l}3.84 \\
3.20\end{array}$ & $\begin{array}{l}3.60 \\
2.98\end{array}$ & $\begin{array}{l}3.62 \\
2.89\end{array}$ & $\begin{array}{l}3.70 \\
2.74\end{array}$ & $\begin{array}{l}3.72 \\
2.78\end{array}$ & $\begin{array}{l}3.50 \\
2.41\end{array}$ & $\begin{array}{l}3.28 \\
2.67\end{array}$ \\
\hline BLACK & 0.090 & 0.106 & 0.119 & 0.130 & 0.107 & 0.111 & 0.098 \\
\hline PROTESTANT & 0.652 & 0.654 & 0.640 & 0.628 & 0.580 & 0.568 & 0.530 \\
\hline CATHOLIC & 0.254 & 0.257 & 0.296 & 0.294 & 0.343 & 0.344 & 0.341 \\
\hline JEWISH & 0.018 & 0.021 & 0.018 & 0.024 & 0.029 & 0.017 & 0.000 \\
\hline COUNTRY & 0.126 & 0.111 & 0.123 & 0.099 & 0.117 & 0.140 & 0.159 \\
\hline FARM & 0.195 & 0.153 & 0.120 & 0.114 & 0.096 & 0.084 & 0.083 \\
\hline SMALL TOWN & 0.317 & 0.329 & 0.308 & 0.328 & 0.287 & 0.307 & 0.311 \\
\hline MID CITY & 0.131 & 0.155 & 0.158 & 0.171 & 0.196 & 0.173 & 0.250 \\
\hline SUB CITY & 0.083 & 0.111 & 0.140 & 0.130 & 0.180 & 0.150 & 0.083 \\
\hline LARGE CITY & 0.148 & 0.141 & 0.151 & 0.157 & 0.125 & 0.146 & 0.114 \\
\hline NEW ENGLAND & 0.059 & 0.044 & 0.046 & 0.048 & 0.056 & 0.038 & 0.068 \\
\hline MID. ATLANTIC & 0.171 & 0.162 & 0.171 & 0.161 & 0.164 & 0.159 & 0.106 \\
\hline E.N. CENTRAL & 0.203 & 0.210 & 0.204 & 0.198 & 0.206 & 0.207 & 0.182 \\
\hline W.N. CENTRAL & 0.096 & 0.091 & 0.086 & 0.086 & 0.083 & 0.069 & 0.091 \\
\hline S. ATLANTIC & 0.149 & 0.144 & 0.139 & 0.140 & 0.131 & 0.157 & 0.129 \\
\hline E.S. CENTRAL & 0.072 & 0.075 & 0.079 & 0.076 & 0.053 & 0.058 & 0.098 \\
\hline W.S. CENTRAL & 0.084 & 0.093 & 0.085 & 0.077 & 0.079 & 0.090 & 0.083 \\
\hline MOUNTAIN & 0.042 & 0.037 & 0.041 & 0.046 & 0.060 & 0.038 & 0.061 \\
\hline PACIFIC & 0.066 & 0.098 & 0.099 & 0.111 & 0.120 & 0.117 & 0.114 \\
\hline FOREIGN & 0.006 & 0.003 & 0.007 & 0.009 & 0.011 & 0.029 & 0.061 \\
\hline
\end{tabular}


Table 7.1: Roles of Parents' Education by Cohort (Male, above 30)

\begin{tabular}{|c|c|c|c|c|c|c|c|c|c|c|c|c|c|c|}
\hline \multirow{3}{*}{$\begin{array}{l}\text { Birth Cohort } \\
\text { PAEDUC }\end{array}$} & \multirow{2}{*}{\multicolumn{2}{|c|}{$1935-39$}} & \multirow{2}{*}{\multicolumn{2}{|c|}{$1940-44$}} & \multicolumn{6}{|c|}{ Dependent variable is EDUC } & \multirow{2}{*}{\multicolumn{2}{|c|}{$1960-64$}} & \multirow{2}{*}{\multicolumn{2}{|c|}{$1965-69$}} \\
\hline & & & & & $1945-49$ & & $1950-54$ & & $1955-59$ & & & & & \\
\hline & $\begin{array}{l}0.113 \\
0.032\end{array}$ & $\star \star \star \star *$ & $\begin{array}{l}0.206 \\
0.026\end{array}$ & $\pm * *$ & $\begin{array}{l}0.197 \\
0.025\end{array}$ & $* * *$ & $\begin{array}{l}0.210 \\
0.026\end{array}$ & $\star \star \star \star t$ & $\begin{array}{l}0.238 \\
0.030\end{array}$ & $* \pm *$ & $\begin{array}{l}0.298 \\
0.037\end{array}$ & $\pm \pi t$ & $\begin{array}{l}0.297 \\
0.067\end{array}$ & $* \pm *$ \\
\hline MAEDUC & $\begin{array}{l}0.225 \\
0.039\end{array}$ & $\star \star \star \star *$ & $\begin{array}{l}0.206 \\
0.031\end{array}$ & \pm \pm & $\begin{array}{l}0.158 \\
0.032\end{array}$ & 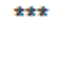 & $\begin{array}{l}0.197 \\
0.031\end{array}$ & 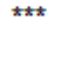 & $\begin{array}{l}0.128 \\
0.038\end{array}$ & $* * *$ & $\begin{array}{l}0.101 \\
0.051\end{array}$ & $*$ & $\begin{array}{l}0.087 \\
0.095\end{array}$ & \\
\hline CONSTANT & $\begin{array}{l}9.616 \\
0.833\end{array}$ & 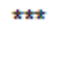 & $\begin{array}{l}9.254 \\
0.711\end{array}$ & $\pm \pm=$ & $\begin{array}{c}10.670 \\
0.769\end{array}$ & $* * *$ & $\begin{array}{c}10.593 \\
0.814\end{array}$ & 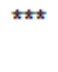 & $\begin{array}{c}10.023 \\
1.018\end{array}$ & $* \pm *$ & $\begin{array}{l}8.980 \\
1.819\end{array}$ & $\pm \pi t$ & $\begin{array}{c}15.639 \\
5.892\end{array}$ & 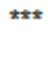 \\
\hline $\begin{array}{l}\text { TEST of } \\
\text { PAEDUC = MAEDUC } \\
\text { (P-value) }\end{array}$ & 0.080 & $\star$ & 0.994 & & 0.432 & & 0.807 & & 0.075 & * & 0.010 & 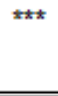 & 0.147 & \\
\hline
\end{tabular}

Table 7.2: Roles of Parents' Education by Cohort (Female, above 30)

\begin{tabular}{|c|c|c|c|c|c|c|c|c|c|c|c|c|c|c|}
\hline Birth Cohort & $1935-39$ & & $1940-44$ & & $1945-49$ & & $1950-54$ & & $1955-59$ & & $1960-64$ & & $1965-69$ & \\
\hline PAEDUC & $\begin{array}{l}0.125 \\
0.024\end{array}$ & 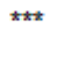 & $\begin{array}{l}0.173 \\
0.021\end{array}$ & $\pm * *$ & $\begin{array}{l}0.165 \\
0.021\end{array}$ & $* * *$ & $\begin{array}{l}0.173 \\
0.023\end{array}$ & 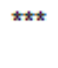 & $\begin{array}{l}0.173 \\
0.024\end{array}$ & $* * *$ & $\begin{array}{l}0.233 \\
0.030\end{array}$ & $\pm \pi t$ & $\begin{array}{l}0.165 \\
0.074\end{array}$ & $* *$ \\
\hline MAEDUC & $\begin{array}{l}0.215 \\
0.028\end{array}$ & $\star \star \star *$ & $\begin{array}{l}0.175 \\
0.027\end{array}$ & $* *$ & $\begin{array}{l}0.173 \\
0.025\end{array}$ & $* * *$ & $\begin{array}{l}0.162 \\
0.028\end{array}$ & $* \pi *$ & $\begin{array}{l}0.210 \\
0.031\end{array}$ & $* \pm *$ & $\begin{array}{l}0.180 \\
0.041\end{array}$ & $\pm x t$ & $\begin{array}{l}0.241 \\
0.088\end{array}$ & $* * *$ \\
\hline CONSTANT & $\begin{array}{l}7.853 \\
0.632\end{array}$ & 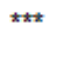 & $\begin{array}{l}8.158 \\
0.603\end{array}$ & $\pm * *$ & $\begin{array}{l}8.907 \\
0.646\end{array}$ & $* * *$ & $\begin{array}{l}8.758 \\
0.749\end{array}$ & 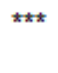 & $\begin{array}{r}10.141 \\
0.937\end{array}$ & $* * *$ & $\begin{array}{l}7.556 \\
1.497\end{array}$ & $\pm x t$ & $\begin{array}{l}7.807 \\
6.420\end{array}$ & \\
\hline $\begin{array}{l}\text { TEST of } \\
\text { PAEDUC = MAEDUC } \\
\text { (P-value) }\end{array}$ & 0.049 & $\star *$ & 0.975 & & 0.833 & & 0.796 & & 0.439 & & 0.388 & & 0.600 & \\
\hline
\end{tabular}


Variable Names and Definition

\begin{tabular}{|c|c|}
\hline Variable Name & Variable Definition \\
\hline $\mathrm{AGE}$ & Respondent's age when he or she was interviewed \\
\hline EDUC & R's years of completed education \\
\hline PAEDUC & R's father years of completed education \\
\hline MAEDUC & R's mother years of completed education \\
\hline MAWKBORN & $\begin{array}{l}\text { MAWKBORN = } 1 \text { if R's mother worked as long as a year } \\
\text { after } R \text { was born and before } R \text { started first grade }\end{array}$ \\
\hline SIBS & Number of siblings \\
\hline BLACK & BLACK $=1$ if $\mathrm{R}$ 's race is black \\
\hline PROTESTANT & PROTESTANT = 1 if $R$ was raised as protestant \\
\hline CATHOLIC & CATHOLIC $=1$ if $\mathrm{R}$ was raised as catholic \\
\hline JEWISH & JEWISH $=1$ if $\mathrm{R}$ was raised as jewish \\
\hline COUNTRY & COUNTRY $=1$ if $R$ lived in open country but not on a farm at age 16 \\
\hline FARM & FARM $=1$ if $R$ lived in a farm at age 16 \\
\hline SMALI TOWN & SMALL TOWN $=1$ if $R$ lived in small city or town (under 50,000 ) at age 16 \\
\hline MID CITY & MID CITY = 1 if $R$ lived in Medium-size city $(50,000-250,000)$ at age 16 \\
\hline SUB CITY & SUB CITY = 1 if $R$ lived in a suburb near a large city at age 16 \\
\hline LARGE CITY & LARGE CITY = 1 if $R$ lived in a large city (above 250,000) at age 16 \\
\hline NEW ENGLAND & $\begin{array}{l}\text { NEW ENGLAND = } 1 \text { if } \mathrm{R} \text { lived in New England at age } 16 . \\
\text { Includes: ME, VT, NH, MA, CT, RI }\end{array}$ \\
\hline MID. ATLANTIC & $\begin{array}{l}\text { MID. ATLANTIC }=1 \text { if } \mathrm{R} \text { lived in the Mid Atlantic region at age } 16 . \\
\text { Includes: NY, NJ, PA }\end{array}$ \\
\hline E.N. CENTRAL & $\begin{array}{l}\text { E.N. CENTRAL = } 1 \text { if } \mathrm{R} \text { lived in the East North Central region at age } 16 . \\
\text { Includes: WI, IL, IN, MI, OH }\end{array}$ \\
\hline W.N. CENTRAL & $\begin{array}{l}\text { W.N. CENTRAL = } 1 \text { if } R \text { lived in the West North Central region at age } 16 . \\
\text { Includes: MN, IA, MO, ND, SD, NE, KS }\end{array}$ \\
\hline S. ATLANTIC & $\begin{array}{l}\text { S. ATLANTIC = } 1 \text { if R lived in the South Atlantic region at age } 16 . \\
\text { Includes: DE, MD, WV, VA, NC, SC, GA, FL, DC }\end{array}$ \\
\hline E.S. CENTRAL & $\begin{array}{l}\text { E.S. CENTRAL = } 1 \text { if } \mathrm{R} \text { lived in the East South Central region at age } 16 . \\
\text { Includes: KY, TN, AL, MS }\end{array}$ \\
\hline W.S. CENTRAL & $\begin{array}{l}\text { W.S. CENTRAL = } 1 \text { if } \mathrm{R} \text { lived in the West South Central region at age } 16 . \\
\text { Includes: AR, OK, LA, TX }\end{array}$ \\
\hline MOUNTAIN & $\begin{array}{l}\text { MOUNTAIN }=1 \text { if } R \text { lived in the region that includes MT, ID, WY, NV, } \\
\text { UT, CO, AZ and NM at age } 16 .\end{array}$ \\
\hline PACIFIC & $\begin{array}{l}\text { PACIFIC }=1 \text { if } \mathrm{R} \text { lived in the Pacific region at age } 16 . \\
\text { Includes: WA, OR, CA, AK, HI }\end{array}$ \\
\hline FOREIGN & FOREIGN $=1$ if $R$ lived in a foreign country at age 16 . \\
\hline
\end{tabular}

